Prepared in cooperation with the U.S. Department of Energy, National Nuclear Security Administration Nevada Site Office, Office of Environmental Management under Interagency Agreement, DE-A152-07NA28100

\title{
Predevelopment Water-Level Contours for Aquifers in the Rainier Mesa and Shoshone Mountain Area of the Nevada Test Site, Nye County, Nevada
}

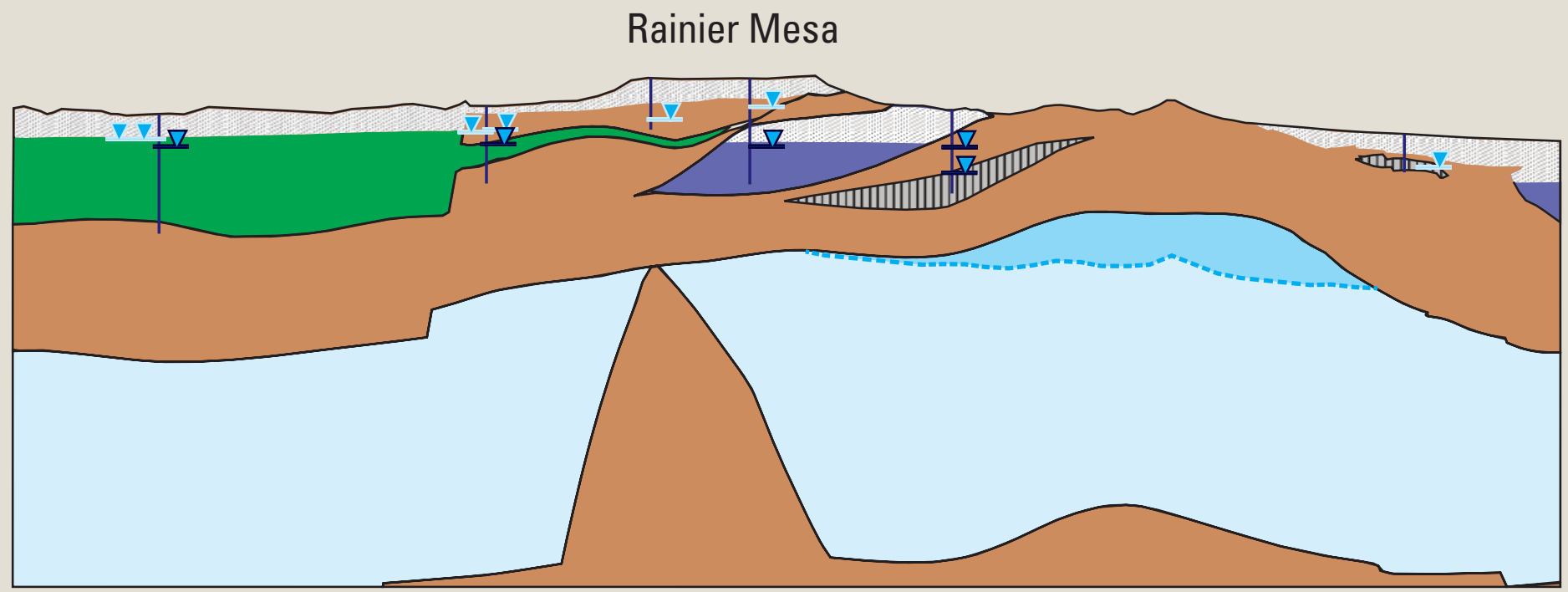

Scientific Investigations Report 2008-5044 



\section{Predevelopment Water-Level Contours for Aquifers in the Rainier Mesa and Shoshone Mountain Area of the Nevada Test Site, Nye County, Nevada}

By Fenelon, Joseph M., Laczniak, Randell J., and Halford, Keith J.

Prepared in cooperation with the U.S. Department of Energy, National

Nuclear Security Administration Nevada Site Office, Office of Environmental

Management under Interagency Agreement, DE-A152-07NA28100

Scientific Investigations Report 2008-5044 


\section{U.S. Department of the Interior DIRK KEMPTHORNE, Secretary}

\section{U.S. Geological Survey \\ Mark D. Myers, Director}

\section{U.S. Geological Survey, Reston, Virginia: 2008}

For product and ordering information:

World Wide Web: http://www.usgs.gov/pubprod

Telephone: 1-888-ASK-USGS

For more information on the USGS--the Federal source for science about the Earth, its natural and living resources, natural hazards, and the environment:

World Wide Web: http://www.usgs.gov

Telephone: 1-888-ASK-USGS

Any use of trade, product, or firm names is for descriptive purposes only and does not imply endorsement by the U.S. Government.

Although this report is in the public domain, permission must be secured from the individual copyright owners to reproduce any copyrighted materials contained within this report.

Suggested citation:

Fenelon, J.M., Laczniak, R.J., and Halford, K.J., 2008, Predevelopment water-level contours for aquifers in the Rainier Mesa and Shoshone Mountain area of the Nevada Test Site, Nye County, Nevada: U.S. Geological Survey Scientific Investigations Report 2008-5044, 38 p. 


\section{Contents}

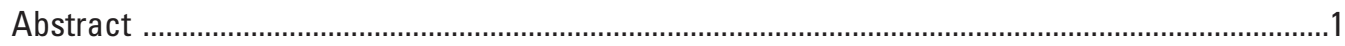

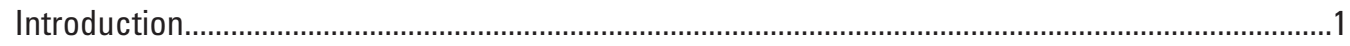

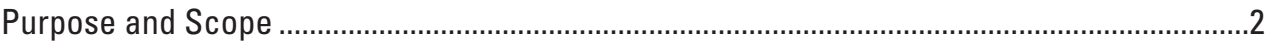

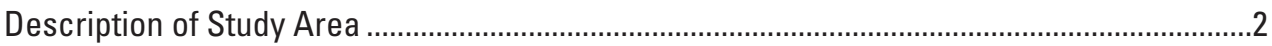

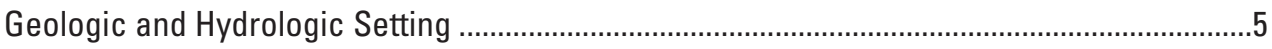

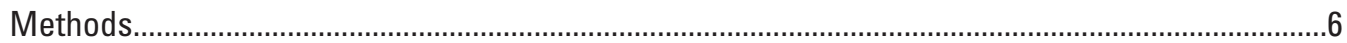

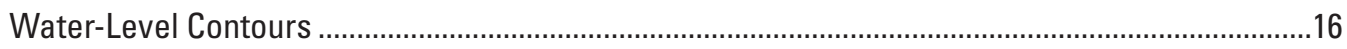

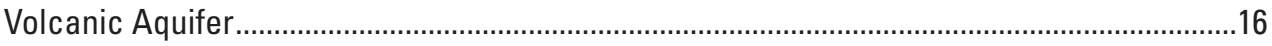

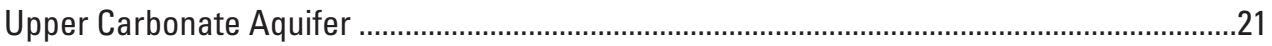

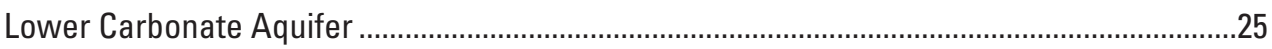

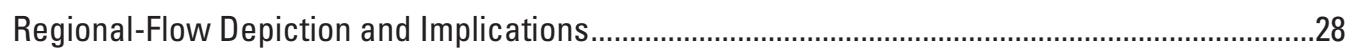

Summary

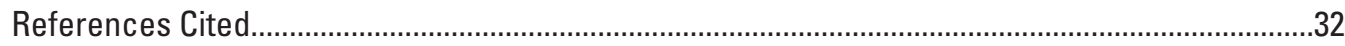

Appendix 1. Water Levels Measured in the Rainier Mesa and Shoshone Mountain Area, Nevada Test Site, Nye County, Nevada, 1957-2007 ...............................................................35

Appendix 2. Mean Water Levels, Well Characteristics, and Water-Level Remarks for Wells Used to Develop Water-Level Contours in the Rainier Mesa and Shoshone Mountain Area, Nevada Test Site, Nye County, Nevada

Appendix 3. Hydrostratigraphic Units and Subsurface Hydrologic Unit Types for Wells in the Rainier Mesa and Shoshone Mountain Area, as Projected From Hydrostratigraphic Framework Models, Nevada Test Site, Nye County, Nevada 


\section{Figures}

Figure 1. Map showing major geologic, topographic, and physiographic features of the Rainier Mesa and Shoshone Mountain area, Nevada Test Site, Nye County,

Nevada

Figure 2. Map showing location of boreholes with water-level measurements that were used to develop water-level contours in the Rainier Mesa and Shoshone Mountain area, Nevada Test Site, Nye County, Nevada

Figure 3. Chart showing aquifer and confining unit classification system used to conceptualize ground-water flow in the Rainier Mesa and Shoshone Mountain area, Nevada Test Site, Nye County, Nevada

Figure 4. Chart showing correlation of subsurface hydrologic unit types (SHUT) and hydrostratigraphic units (HSU) for the Rainier Mesa and Shoshone Mountain area, Nevada Test Site, Nye County, Nevada

Figure 5. Example from appendix 1 Excel workbook showing water levels that were analyzed in well "UE-8e (2295 ft)", Nevada Test Site, Nye County, Nevada

Figure 6. Example from appendix 3 Excel workbook showing hydrostratigraphic units and their relation to water level and open intervals in well "UE-8e $(2295 \mathrm{ft})$ ", Nevada Test Site, Nye County, Nevada

Figure 7. North-south and west-east sections through the Rainier Mesa and Shoshone Mountain area, Nevada Test Site, Nye County, Nevada showing distribution of subsurface hydrologic unit types (upper sections) and designations of continuous and isolated aquifers (lower sections)

Figure 8. Map showing predevelopment water-level altitudes and contours for continuous volcanic aquifers and distribution of isolated volcanic aquifers in the Rainier Mesa and Shoshone Mountain area, Nevada Test Site, Nye County, Nevada

Figure 9. Maps showing alternative interpretations of predevelopment water-level altitudes and contours for continuous upper carbonate aquifers and distribution of isolated upper carbonate aquifers in the Rainier Mesa and Shoshone Mountain area, Nevada Test Site, Nye County, Nevada

Figure 10. Map showing predevelopment water-level altitudes and contours for continuous lower carbonate aquifers in the Rainier Mesa and Shoshone Mountain area, Nevada Test Site, Nye County, Nevada

Figure 11. Map showing tributary ground-water flow systems and general directions of ground-water flow in the Rainier Mesa and Shoshone Mountain area, Nevada Test Site, Nye County, Nevada

\section{Table}

Table 1. Water-level data and well characteristics for wells used to develop water-level contours in the Rainier Mesa and Shoshone Mountain area, Nevada Test Site, Nye County, Nevada 


\section{Conversion Factors and Datums}

Conversion Factors

\begin{tabular}{lcl}
\hline Multiply & By & To obtain \\
\hline inch (in.) & 2.54 & centimeter $(\mathrm{cm})$ \\
foot (ft) & 0.3048 & meter $(\mathrm{m})$ \\
mile (mi) & 1.609 & kilometer $(\mathrm{km})$ \\
gallon (gal) & 0.003785 & cubic meter $\left(\mathrm{m}^{3}\right)$ \\
million gallons $(\mathrm{Mgal})$ & 3,785 & cubic meter $\left(\mathrm{m}^{3}\right)$ \\
gallon per minute $(\mathrm{gal} / \mathrm{min})$ & 0.06309 & liter per second $(\mathrm{L} / \mathrm{s})$ \\
\hline
\end{tabular}

Temperature in degrees Fahrenheit $\left({ }^{\circ} \mathrm{F}\right)$ may be converted to degrees Celsius $\left({ }^{\circ} \mathrm{C}\right)$ as follows:

$$
{ }^{\circ} \mathrm{C}=\left({ }^{\circ} \mathrm{F}-32\right) / 1.8 \text {. }
$$

Datums

Vertical coordinate information is referenced to the National Geodetic Vertical Datum of 1929 (NGVD 29).

Horizontal coordinate information is referenced to the North American Datum of 1983 (NAD 83) unless otherwise stated.

Altitude, as used in this report, refers to distance above or below (-) the vertical datum. 
This page intentionally left blank. 


\title{
Predevelopment Water-Level Contours for Aquifers in the Rainier Mesa and Shoshone Mountain area of the Nevada Test Site, Nye County, Nevada
}

\author{
By Joseph M. Fenelon, Randell J. Laczniak, and Keith J. Halford
}

\begin{abstract}
Contaminants introduced into the subsurface of the Nevada Test Site at Rainier Mesa and Shoshone Mountain by underground nuclear testing are of concern to the U.S. Department of Energy and regulators responsible for protecting human health and safety. Although contaminants were introduced into low-permeability rocks above the regional flow system, the potential for contaminant movement away from the underground test areas and into the accessible environment is greatest by ground-water transport. The primary hydrologic control on this transport is evaluated and examined through a series of contour maps developed to represent the water-level distribution within each of the major aquifers underlying the area. Aquifers were identified and their extents delineated by merging and analyzing multiple hydrostratigraphic framework models developed by other investigators from existing geologic information. The contoured water-level distribution in each major aquifer was developed from a detailed evaluation and assessment of available water-level measurements. Multiple spreadsheets that accompany this report provide pertinent water-level and geologic data by well or drill hole.

Aquifers are mapped, presented, and discussed in general terms as being one of three aquifer types-volcanic aquifer, upper carbonate aquifer, or lower carbonate aquifer. Each of these aquifer types was subdivided and mapped as independent continuous and isolated aquifers, based on the continuity of its component rock. Ground-water flow directions, as related to the transport of test-generated contaminants, were developed from water-level contours and are presented and discussed for each of the continuous aquifers. Contoured water-level altitudes vary across the study area and range from more than 5,000 feet in the volcanic aquifer beneath a recharge area in the northern part of the study area to less than 2,450 feet in the lower carbonate aquifer in the southern part of the study area. Variations in water-level altitudes within any single continuous aquifer range from a few hundred feet in a lower carbonate aquifer to just more than 1,100 feet in a volcanic aquifer. Flow directions throughout the study area are dominantly
\end{abstract}

southward with minor eastward or westward deviations. Primary exceptions are westward flow in the northern part of the volcanic aquifer and eastward flow in the eastern part of the lower carbonate aquifer. Northward flow in the upper and lower carbonate aquifers in the northern part of the study area is possible but cannot be substantiated because data are lacking.

Interflow between continuous aquifers is evaluated and mapped to define major flow paths. These flow paths delineate tributary flow systems, which converge to form the regional ground-water flow system. The implications of these tributary flow paths in controlling transport away from the underground test areas at Rainier Mesa and Shoshone Mountain are discussed. The obvious data gaps contributing to uncertainties in the delineation of aquifers and development of water-level contours are identified and evaluated.

\section{Introduction}

The potential for transport of radionuclides and other testgenerated contaminants away from areas of past underground nuclear testing at the Nevada Test Site (NTS) is of great concern and interest to the U.S. Department of Energy and to State and certain Federal regulatory agencies. Currently, numerical models are being developed to simulate the flow of ground water and the transport of contaminants away from underground tests detonated in the subsurface of Rainier Mesa and Shoshone Mountain (RMSM). As part of this effort, geologic data and well information have been integrated spatially to create a three-dimensional hydrostratigraphic framework model (HFM) of the local hydrostratigraphy. The HFM portrays the ground-water flow system as a complex arrangement of aquifers and intervening confining units. This hydrostratigraphic framework serves as the foundation for the ground-water flow and transport models, which will be used to formulate decisions related to the remediation of contaminants introduced into the flow system as a consequence of underground testing. 
The direction and rate of transport within the local aquifers is controlled in part by the hydraulic-head gradient. Hydraulic head defines the water potential at a given location and commonly is estimated by converting a measurement of depth to water in a well to a water-level altitude. The spatial distribution of water-level altitudes across the RMSM area has been portrayed historically by maps showing a single set of generalized water-level contours. These maps either are regional in scale (Fenske and Carnahan, 1975; Waddell and others, 1984; Laczniak and others, 1996; D'Agnese and others, 1998) or focus specifically on areas to the west (Blankennagel and Weir, 1973; O'Hagan and Laczniak, 1996), southwest (Robinson, 1984; Ervin and others, 1993; Tucci and Burkhardt, 1995), or east of the study area (Doty and Thordarson, 1983; Hale and others, 1995). Water-level maps showing separate sets of contours for rocks of Cenozoic and pre-Tertiary age in the areas surrounding, but not including, the study area were constructed by Winograd and Thordarson (1975).

Maps generalizing the water-level distribution with a single set of contours, by their very nature, ignore vertical flow components and represent the complex subsurface geology of the area as a single, continuous, regionally extensive flow system. Contrarily, as is indicated by published hydrostratigraphic framework models, the ground-water flow system is made up of multiple aquifers that are separated hydraulically by confining units. The degree of hydraulic interconnection between these aquifers varies depending on the permeability of the intervening confining rock. The hydraulic separation of the aquifers by low-permeability units creates multiple, semi-independent systems, in which the primary flow directions and rates are controlled by the head gradient within the aquifer. The directions of flow between two adjacent aquifers may or may not be similar. Successful and accurate simulation of the potential transport of testgenerated contaminants requires a sound understanding of the rate and direction of ground-water flow within each aquifer. This understanding can be gained by a more thorough integration of hydrologic and geologic information and an accurate depiction of the water-level contours and corresponding hydraulic gradients within each of the major aquifers.

\section{Purpose and Scope}

The purpose of this report is to show the areal distribution of aquifers beneath the RMSM area and to develop maps of water-level contours that define the likely direction of groundwater flow within each of the major aquifers. These contour maps are intended to represent natural or predevelopment ground-water conditions. Predevelopment conditions are assumed to represent steady-state or near steady-state conditions prior to any human activities in the area, such as pumping and nuclear testing. The contour maps are designed to conceptualize and describe ground-water flow within and between aquifers in the multi-aquifer ground-water flow system. The maps and their companion water levels can serve as calibration targets for future flow models and help in determining likely ground-water flow paths.

Maps included in the report provide a generalized delineation of the spatial distribution of aquifers, major flow directions within these aquifers, and potential recharge areas. Maps also show areas of lateral inflow to and outflow from the major aquifers. The report provides well-construction and water-level data derived from boreholes drilled in the RMSM area. Open intervals in a well are associated with aquifers and confining units defined and delineated by the three-dimensional hydrostratigraphic model of the RMSM area (National Security Technologies, LLC, 2007). The wellconstruction, water-level, and hydrostratigraphic data can be displayed with interactive spreadsheets that accompany the report.

\section{Description of Study Area}

The study area is about 90 mi northwest of Las Vegas in Nye County, Nevada, on the NTS and encompasses Rainier Mesa and Shoshone Mountain (fig. 1). Together, these two topographic highlands form the eastern extent of an extensive volcanic plateau that spans most of the western half of the NTS. The topography of the area is defined by the many varying physiographic and topographic features including mesas, mountains, and valleys. Pahute Mesa and Timber Mountain bound the study area on the west and the Belted Range, Yucca Flat, and CP Hills on the east (fig. 1). Altitudes in the area range from about 4,500 ft in Mid Valley and Yucca Flat to about 6,800 ft at Shoshone Mountain and 7,600 ft at Rainier Mesa.

The Rainier Mesa and Shoshone Mountain areas were used to test underground nuclear devices, primarily in tunnel complexes (fig. 2) mined into low-permeability, zeolitized tuff. The complexes were mined westward into the steep eastern sidewall of the local highland that demarcates the transition from more typical basin and range to upland plateau. All underground tests in the RMSM area were detonated above the regional water table. Sixty-six of these tests were detonated in tunnel complexes and two were detonated in vertical shafts (U.S. Department of Energy, 2000).

The climate of the area is described as semiarid high desert and is characterized by low precipitation and humidity and large fluctuations in daily and annual temperatures. Annual precipitation ranges from less than 5 in. on the valley floor of Yucca Flat to nearly 12 in. on Rainier Mesa (Soulé, 2006). Precipitation occurs primarily in winter to early spring and in mid-summer. Precipitation falls primarily as rain and as snow at high altitudes during the winter months. Temperatures are cold in the winter and hot in the summer, and range from lows of near $0^{\circ} \mathrm{F}$ in mid-winter to highs of more than $100^{\circ} \mathrm{F}$ in mid-summer. Temperatures generally are 10 to $20^{\circ} \mathrm{F}$ cooler on the mesas and mountains than in the valleys and can fluctuate daily by more than $30^{\circ} \mathrm{F}$. 


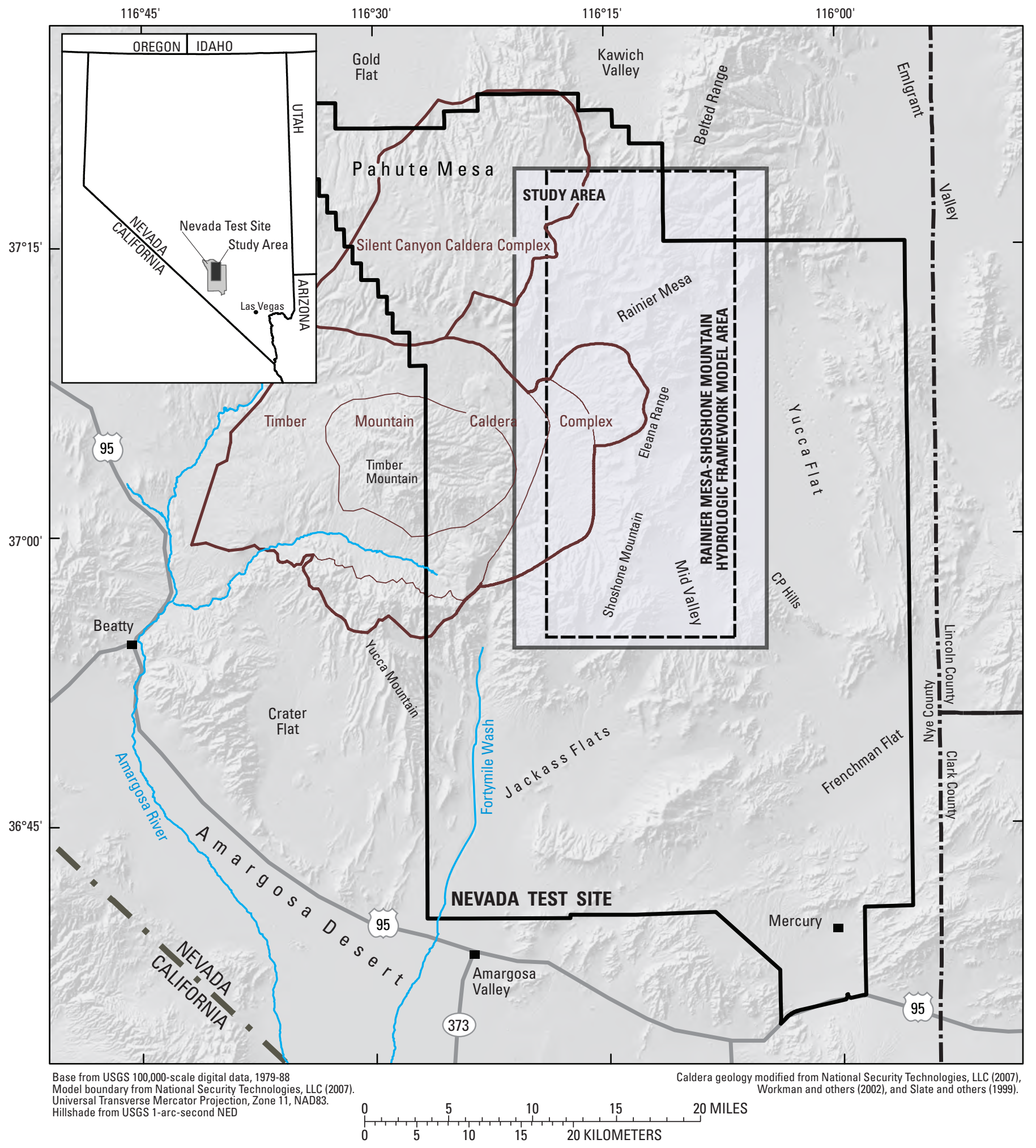

Figure 1. Major geologic, topographic, and physiographic features of the Rainier Mesa and Shoshone Mountain area, Nevada Test Site, Nye County, Nevada. 


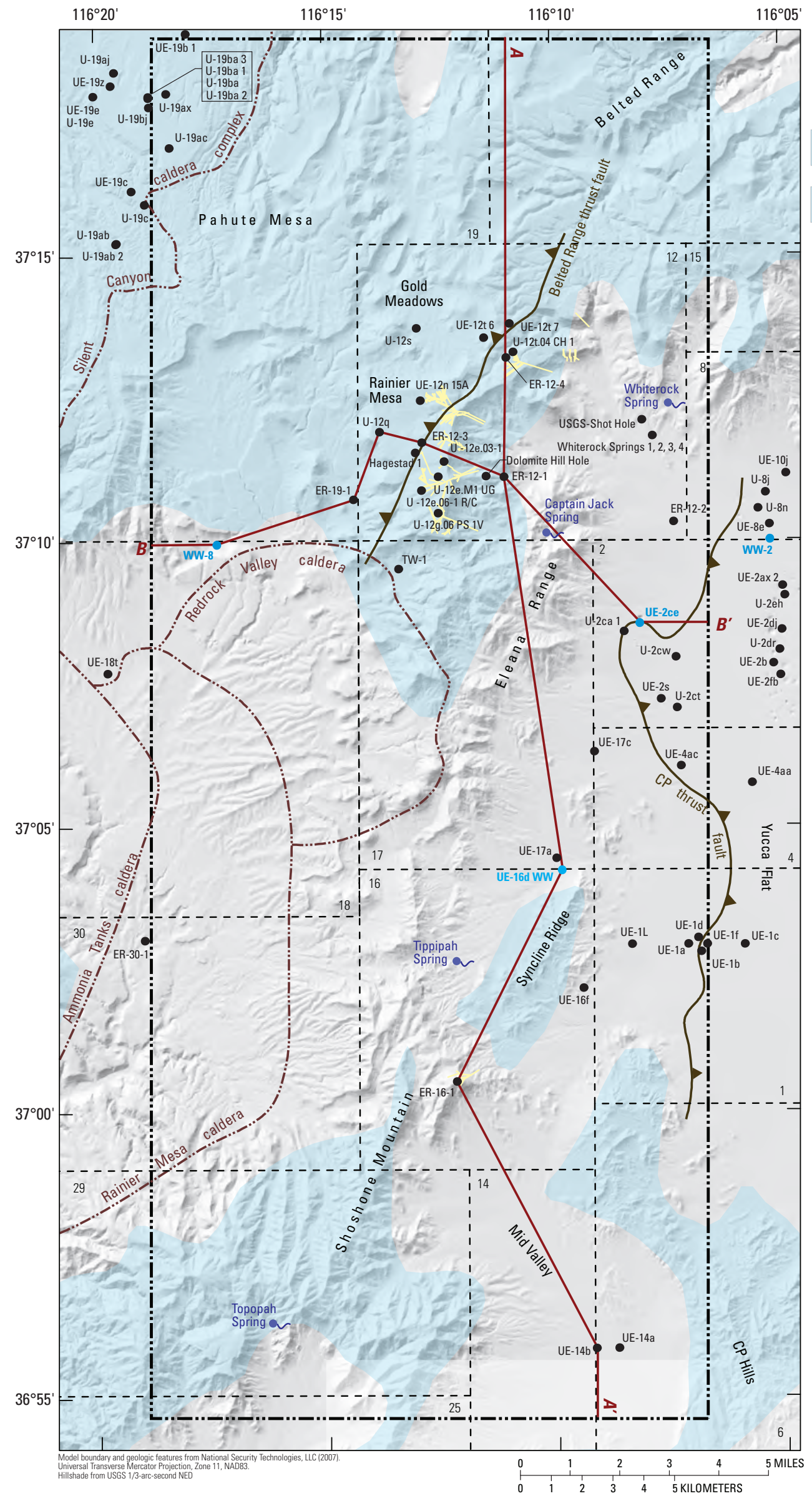

\section{EXPLANATION}

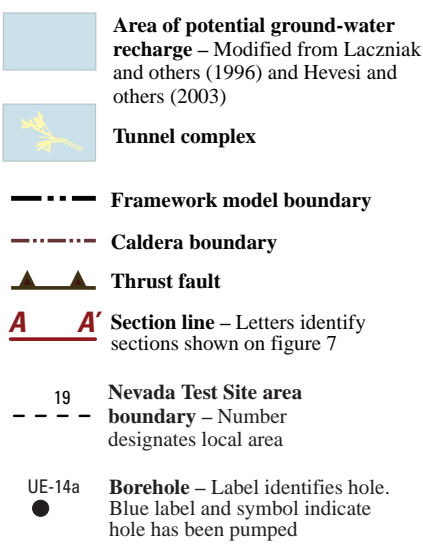

Figure 2. Location of boreholes with water-level measurements that were used to develop water-level contours in the Rainier Mesa and Shoshone Mountain area, Nevada Test Site, Nye County, Nevada.

Figure is designed to be printed on
$11 \times 17-i n c h$ page. To obtain
full-scale image, go to
http://pubs.usgs.gov/sir/2008/5044/




\section{Geologic and Hydrologic Setting}

The Rainier Mesa and Shoshone Mountain area forms a volcanic upland preserved in part by a dense cap of welded volcanic tuff. The caprock is underlain by a thick sequence of less-dense and less-resistive Tertiary-age bedded tuffs that are underlain by thousands of feet of massive bedrock of pre-Tertiary age. The older bedrock sequence consists of Precambrian and Paleozoic-age sedimentary rock deposited by ancient transgressing and regressing seas. The sedimentary bedrock is intruded locally by Cretaceous-age granites and granodiorites. The entire assemblage is overlain by the aforementioned Miocene-age volcanic rock and variably thick deposits of primarily Miocene-age and younger sedimentary rocks and partially consolidated to unconsolidated deposits of sand, gravel, and clay.

The sequence and position of the local rocks have been modified by structures associated with the complicated tectonic and volcanic history of the area. After deposition, the Paleozoic-age and older rocks in the area were subjected to compressive forces that warped and altered the bedrock by thrusting and folding. Following this period of compression, the rocks were subjected to extensional forces that pulled apart the bedrock and produced normal faults. Concurrent with the normal faulting, Cretaceous-age granitic magma intruded into the local area. This initial deformational episode lasted through the Mesozoic Era and was followed by a period of subdued tectonic activity; during this time the exposed bedrock surface was reshaped by erosion. This interlude was followed by a second period of extension when the rocks again were pulled apart along low-angle normal and strikeslip faults. The downdropping of bedrock blocks began the formative stages of the generally north-south trending mountain ranges and valleys that characterize the Basin and Range physiographic province of today. Successive volcanic eruptions in the late-Tertiary Period produced at least six large and partially overlapping calderas in the NTS area that make up the southwestern Nevada volcanic field (Sawyer and others, 1994). Rocks extruded by active volcanoes and local landslides and eroded sediments filled the local calderas. The volcanic rocks blanketed the surrounding region with extensive sheets of tuff and local lava flows. The relatively young, Tertiary-age tuff deposits form the uppermost layered sequence of rocks in the RMSM area. The Quaternary Period was dominated primarily by erosion and basin-filling processes that shaped the area into its modern topography.

The rocks of the study area form a complex interconnected series of aquifers and confining units, commonly dissected and offset by local faulting. The preTertiary bedrock units are classified according to their hydrologic properties into two basic categories: carbonate aquifers and siliceous confining units. The siliceous confining units are composed of siliciclastic and granitic rocks. The Tertiary-age volcanic rocks form volcanic aquifers and volcanic confining units, and the Tertiary and Quaternaryage basin-fill deposits form alluvial aquifers and alluvial confining units. In the carbonate and volcanic aquifers, ground water moves primarily through secondary fracture openings that occasionally are enhanced by dissolution. In the alluvial aquifer, ground water moves through interstitial openings between grains. Geologic structures, such as faults, commonly influence the flow of ground water. Faults can impede flow by juxtaposing a less permeable rock against a more permeable rock. Alternatively, faults can enhance flow, primarily along strike because of the locally increased secondary permeability caused by intense crushing and fracturing of the rock within the fault zones.

Ground water generally flows through the aquifers in a southerly direction toward downgradient discharge areas south and southwest of the study area in Beatty, Amargosa Desert, and Death Valley (Winograd and Thordarson, 1975; Laczniak and others, 1996). Some ground water is discharged from the aquifers by the pumping of wells. Local pumping began in 1951, and through 2006, about 24 billion gallons of ground water have been pumped from the NTS, primarily from 16 wells (U.S. Geological Survey, 2008). Within the RMSM area, wells completed in four boreholes (WW-2, WW-8, UE-2ce, and UE-16d WW; fig. 2) have had significant (greater than 1 million gallons) amounts of water withdrawn for supply or investigative purposes. About 3.3 billion gallons of water were withdrawn from these wells from 1962 to 2006.

Much of the ground water flowing beneath the NTS region originates from precipitation falling on highlands at and to the north of the NTS. Locally, water recharges the ground-water flow system beneath upland areas in the western part of the NTS (fig. 2). This local recharge area generally is bounded on the east by Rainier Mesa and Shoshone Mountain. Precipitation falling on Rainier Mesa and other nearby areas of high precipitation collects in the fractures and openings that dissect the caprock. Some of this trapped water infiltrates downward through interconnected fractures or through the rock matrix to depths beyond the influence of active evaporation and transpiration (Russell and others, 1987). The less-permeable volcanic tuff present beneath Rainier Mesa and elsewhere beneath these upland areas impedes the downward movement of water through interconnected fractures, creating local zones of perched and semi-perched ground water (Thordarson, 1965). The term "semi-perched" serves to distinguish zones of shallow, elevated water that are underlain by saturated rocks from perched zones, which by definition are underlain by unsaturated rocks (Meinzer, 1923). The few springs that are present in the study area (fig. 2) are low flow and supported by perched and semi-perched water that moves laterally until it intersects the land surface and discharges. 
The recognition and delineation of a regional saturated zone beneath the upland recharge areas is complicated by the presence of perched water. Recharge on eastern Pahute Mesa and Rainier Mesa has created a local water-level mound that influences ground-water flow directions in the perched and semi-perched zones and in the underlying shallow saturated flow system. Water within the unsaturated rock or in semiperched and perched zones beneath the Rainier Mesa and Shoshone Mountain underground test areas may move test-generated contaminants downward into more regional, saturated, permeable rock. Here, transport is controlled primarily by ground-water flow-the rate and direction of which depends on the permeability of the host rock and on local and regional differences in hydraulic head.

\section{Methods}

The general approach used to conceptualize ground-water flow through the study area was to delineate the extent of the rocks forming the three primary aquifer types-volcanic, upper carbonate, and lower carbonate (fig. 3). Discrete aquifers identified within each of these aquifer types are classified as either continuous or isolated aquifers (fig. 3). Continuous aquifers are hydraulically connected to adjacent aquifers and together form part of a larger flow system, whereas isolated aquifers are hydraulically restricted and generally drain only to adjacent confining units. One or more continuous aquifers form tributary flow systems (fig. 3), a term used in this report to imply a small or intermediate flow system that feeds water to a more extensive regional flow system. Water levels in each of the continuous aquifers delineated in the study area were contoured to determine general flow directions and interactions with other continuous aquifers and adjacent confining units.

The first step in the flow conceptualization process was to identify and delineate the continuous and isolated aquifers in the RMSM area. These aquifers were identified and mapped using a composite hydrostratigraphic framework developed by merging previously constructed three-dimensional hydrostratigraphic framework models (HFMs) for the RMSM, Yucca Flat, and Pahute Mesa areas (Bechtel Nevada, 2002, 2006; National Security Technologies, LLC, 2007). During each of these framework-development efforts, a base HFM was constructed that represented the geologist's favored interpretation of the distribution of hydrostratigraphic units across the modeled area. Additionally, several alternative
HFMs were developed within each area to represent the different unit distributions that are geologically possible and potentially would alter ground-water flow paths away from areas of underground nuclear testing. In the RMSM HFM report (National Security Technologies, LLC, 2007), one base and four alternative frameworks were developed.

Each HFM is composed of hydrostratigraphic units (HSUs) that consist of one or more stratigraphic units with similar geologic and hydraulic properties. The 45 HSUs identified in the RMSM base and alternative HFMs (National Security Technologies, LLC, 2007) form the hydrogeologic foundation used to develop the conceptualization of groundwater flow presented in this report (fig. 4). The HSUs evaluated as part of this study include 21 aquifers, 22 confining units, and 2 composite units (a combination of aquifer and confining unit).

Framework HSUs were grouped into generalized unit types on the basis of (1) whether the HSU was classified as an aquifer, composite unit, or confining unit; (2) rock type; and (3) stratigraphic position relative to other HSUs (fig. 3). The combining of HSUs reduced the number of subsurface units to seven (figs. 3 and 4). These seven units herein are referred to as subsurface hydrologic unit types, or SHUTs, and include:

- alluvial aquifer,

- volcanic aquifer,

- volcanic composite unit,

- volcanic confining unit,

- upper carbonate aquifer ${ }^{1}$,

- siliceous confining unit, and

- lower carbonate aquifer.

The three-dimensional configuration and distribution of these SHUTs were developed by constructing and evaluating numerous cross sections and horizontal slices through the HFMs. Based on this evaluation, similar interconnected SHUTs were combined to form the principal aquifer- and confining-unit types of the RMSM area. Three principal aquifer types (referred to as the volcanic aquifer, upper carbonate aquifer, and lower carbonate aquifer) and one confining unit (the regional confining unit) were identified by this process (fig. 3). The volcanic aquifer includes the overlying alluvial aquifer and the volcanic composite unit. Only the saturated part of each aquifer type was mapped and contoured. For example, the volcanic aquifer is not mapped on the east side of Rainier Mesa where it is unsaturated or is known to contain only perched or semi-perched water.

\footnotetext{
${ }^{1}$ The upper carbonate aquifer SHUT, as defined for this report, is consistent with the upper carbonate aquifer defined by Laczniak and others (1996). This SHUT includes the upper carbonate aquifer HSU (Pennsylvanian-age Tippipah Limestone) and older Devonian-age to Cambrian-age carbonate rocks that structurally overlie the upper clastic confining unit HSU as a result of low-angle faulting (fig. 4).
} 


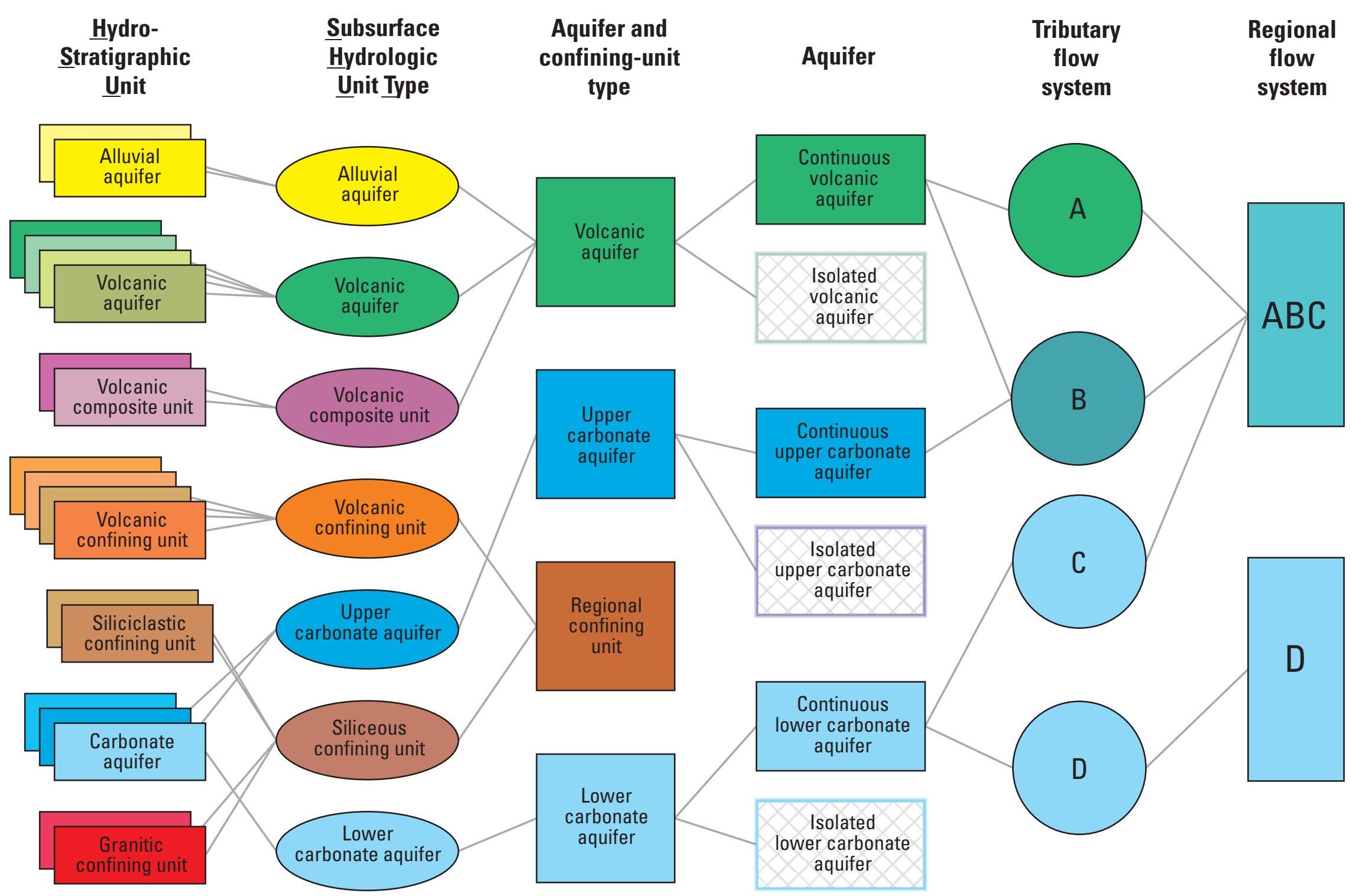

Figure 3. Aquifer and confining unit classification system used to conceptualize ground-water flow in the Rainier Mesa and Shoshone Mountain area, Nevada Test Site, Nye County, Nevada. 


\begin{tabular}{|c|c|c|c|}
\hline SHUT Description & SHUT & HSU & HSU Description \\
\hline \multirow{3}{*}{$\begin{array}{l}\text { Alluvial aquifer } \\
\text { Volcanic composite unit }\end{array}$} & AAO & AA & Alluvial aquifer \\
\hline & VCM & FCCM & Fortymile Canyon composite unit \\
\hline & & TMUVTA & Timber Mountain upper vitric-tuff aquifer \\
\hline \multirow[t]{2}{*}{ Volcanic aquifer } & VAO & TMWTA & Timber Mountain welded-tuff aquifer \\
\hline & & TMLVTA & Timber Mountain lower vitric-tuff aquifer \\
\hline \multirow{2}{*}{$\begin{array}{l}\text { Volcanic composite unit } \\
\text { Volcanic confining unit }\end{array}$} & VCM & TMCM & Timber Mountain composite unit \\
\hline & VCU & RMBCU & Rainier Mesa breccia confining unit \\
\hline \multirow{2}{*}{ Siliceous confining unit } & \multirow{2}{*}{ SCU } & ATICU & Ammonia Tanks intrusive confining unit \\
\hline & & RMICU & Rainier Mesa intrusive confining unit \\
\hline \multirow{4}{*}{$\begin{array}{l}\text { Volcanic aquifer } \\
\text { Volcanic confining unit } \\
\text { Volcanic aquifer } \\
\text { Volcanic confining unit }\end{array}$} & VAO & TCA & Tiva Canyon aquifer \\
\hline & VCU & SCVCU & Subcaldera volcanic confining unit \\
\hline & VAO & PVTA & Paintbrush vitric-tuff aquifer \\
\hline & VCU & UTCU & Upper tuff confining unit \\
\hline \multirow{4}{*}{ Volcanic aquifer } & \multirow{4}{*}{ VAO } & TSA & Topopah Spring aquifer \\
\hline & & LVTA & Lower vitric-tuff aquifer \\
\hline & & CHVTA & Calico Hills vitric-tuff aquifer \\
\hline & & YMCHLFA & Yucca Mountain/Calico Hills lava-flow aquifer \\
\hline \multirow{3}{*}{$\begin{array}{l}\text { Siliceous confining unit } \\
\text { Volcanic confining unit }\end{array}$} & SCU & CHICU & Calico Hills intrusive confining unit \\
\hline & VCU & UTCU2 & Upper tuff confining unit 2 \\
\hline & \multirow{3}{*}{ VAO } & KA & Kearsarge aquifer \\
\hline \multirow[t]{2}{*}{ Volcanic aquifer } & & SWA & Stockade Wash aquifer \\
\hline & & LVTA2 & Lower vitric-tuff aquifer 2 \\
\hline \multirow{2}{*}{ Volcanic confining unit } & \multirow{2}{*}{ vCU } & BFCU & Bullfrog confining unit \\
\hline & & UTCU1 & Upper tuff confining unit 1 \\
\hline \multirow{2}{*}{ Volcanic aquifer } & \multirow{2}{*}{ VAO } & BRA & Belted Range aquifer \\
\hline & & LVTA1 & Lower vitric-tuff aquifer 1 \\
\hline \multirow{3}{*}{$\begin{array}{l}\text { Volcanic confining unit } \\
\text { Siliceous confining unit } \\
\text { Volcanic confining unit }\end{array}$} & VCU & BRCU & Belted Range confining unit \\
\hline & SCU & SCICU & Silent Canyon intrusive confining unit \\
\hline & VCU & LTCU & Lower tuff confining unit \\
\hline \multirow{3}{*}{$\begin{array}{l}\text { Volcanic aquifer } \\
\text { Volcanic confining unit } \\
\text { Volcanic aquifer }\end{array}$} & VAO & TUBA & Tub Spring aquifer \\
\hline & VCU & OSBCU & Oak Spring Butte confining unit \\
\hline & VAO & RVA & Redrock Valley aquifer \\
\hline \multirow{2}{*}{ Volcanic confining unit } & \multirow{2}{*}{ VCU } & RVBCU & Redrock Valley breccia confining unit \\
\hline & & LTCU1 & Lower tuff confining unit 1 \\
\hline \multirow{2}{*}{$\begin{array}{l}\text { Siliceous confining unit } \\
\text { Volcanic confining unit }\end{array}$} & SCU & RVICU & Redrock Valley intrusive confining unit \\
\hline & VCU & ATCU & Argillic tuff confining unit \\
\hline \multirow{2}{*}{ Siliceous confining unit } & \multirow{2}{*}{ SCU } & MGCU & Mesozoic granite confining unit \\
\hline & & LCCU1 & Lower clastic confining unit thrust plate \\
\hline \multirow{2}{*}{$\begin{array}{l}\text { Upper carbonate aquifer } \\
\text { Siliceous confining unit }\end{array}$} & UCA & LCA3 & Lower carbonate aquifer thrust plate \\
\hline & SCU & UCCU1 & Upper clastic confining unit thrust plate 1 \\
\hline \multirow{2}{*}{ Upper carbonate aquifer } & UCA & LCA3-1 & Lower carbonate aquifer thrust plate 1 \\
\hline & UCA & UCA & Upper carbonate aquifer \\
\hline Siliceous confining unit & SCU & UCCU & Upper clastic confining unit \\
\hline Lower carbonate aquifer & LCA & LCA & Lower carbonate aquifer \\
\hline Siliceous confining unit & SCU & LCCU & Lower clastic confining unit \\
\hline
\end{tabular}

Figure 4. Correlation of subsurface hydrologic unit types (SHUT) and hydrostratigraphic units (HSU) for the Rainier Mesa and Shoshone Mountain area, Nevada Test Site, Nye County, Nevada. For additional description of these units, see worksheet "SHUTtoHSU_Chart" in appendix 3. 
Two HFMs were used to develop the aquifer distributions in the RMSM model area. The primary HFM used in this report is an alternative HFM identified by National Security Technologies, LLC (2007) as the "LCA3 at bottom of Well ER-12-1" alternative model. The only difference between this alternative HFM and the National Security Technologies, LLC (2007) base HFM is in the area of borehole ER-12-1, located just east of Rainier Mesa. Carbonate rock encountered at the bottom of borehole ER-12-1, which was modeled as lower carbonate aquifer in the base HFM, is modeled in the alternative HFM as a local, subhorizontal thrust sheet of carbonate rock (LCA3-1) that structurally is isolated from the lower carbonate aquifer. The alternative HFM is used in this report because the aquifer distribution developed from the alternative is more consistent with hydrologic conditions, as indicated by measured water levels in borehole ER-12-1. A second alternative HFM was used in this report specifically to delineate an alternative extent of the upper carbonate aquifer, which would result in a different interpretation of potential transport. This HFM, identified in National Security Technologies, LLC (2007) as the "No Redrock Valley Caldera" alternative model differs from the base HFM by the absence of the Redrock Valley caldera and its associated deposits and the presence of a more extensive section of upper carbonate aquifer. The Redrock Valley caldera, proposed by National Security Technologies, LLC (2007), is supported by an anomalous basement depression originally identified by Hildenbrand and others (2006) from gravity data but its existence has not been confirmed by borehole data.

In addition to determining the distribution of aquifers in the study area, water levels from 172 discrete open intervals in 84 boreholes (appendix 1) were analyzed. Many of these boreholes are concentrated in areas of past underground testing in the northwestern (Pahute Mesa), north-central (Rainier Mesa), and east-central (Yucca Flat) parts of the study area (fig. 2). Each unique open interval (for example, a temporary packed interval or a monitoring tube installed above a grouted section of a borehole) is referred to as a well in this report. Multi-well boreholes provide information on the changes in water-level altitude with depth. Naming conventions for wells and boreholes referred to in this report are as follows. A well that is the sole completion interval in a borehole is assigned the name of the borehole. In boreholes with multiple completions, well names typically are differentiated from each other by a parenthetical expression added after the borehole name-for example: "UE-12t 6 (1378 ft)". A single number in the parenthetical expression refers to the depth of the well; two numbers separated by a dash refer to the depth of the top and bottom of the open interval in the well. In some cases, a well name consists of the borehole name and one of three non-parenthetical expressions (main, piezometer, or WW) that follow the borehole name. All well names in the text of this report are enclosed in quotes for clarity.
Approximately 3,400 water levels were measured in the 172 wells from 1957 to 2007 . Water levels measured in each well were used to define predevelopment conditions in each aquifer. Each water-level measurement in the study area was reviewed for correctness and accuracy, assigned to the proper open interval, and remarked to document the hydrologic conditions occurring at the time of measurement. The evaluation ensures the integrity of the data and identifies the water levels that best represent predevelopment conditions. A large part of the water-level analysis was supported by on-going and completed comprehensive evaluations of water levels on the NTS (Fenelon, 2000, 2005, 2006). All water levels and well-construction information are stored in the USGS National Water Information System (NWIS) database and can be accessed from the world-wide web at http://waterdata.usgs.gov/nv/nwis/gw.

Hydrographs and locations for the 172 wells can be displayed interactively from a Microsoft ${ }^{\circledR}$ Excel workbook (appendix 1). The workbook is designed to be an easy-to-use tool to view water levels and other associated information for wells in the study area. Information for an individual well can be selected by using the AutoFilter option available in Excel. An example of the information available in the appendix is provided for well "UE-8e (2295 ft)" in figure 5 . The information presented on the page includes measurement method, accuracy, and status for each water level.

Nearly all water-level altitudes computed from depth-towater measurements provided in appendix 1 are considered accurate to within $2 \mathrm{ft}$. In most cases, actual depth-to-water and land-surface altitude measurements are accurate to $1 \mathrm{ft}$ or less, depending on the method of measurement. Water-level measurement errors caused by borehole deviation generally are less than $0.5 \mathrm{ft}$. Where errors are larger, the measured water levels were corrected for borehole deviation. The only measurements requiring correction in the study area were those made in boreholes WW-2, UE-10j, and ER-16-1. Water levels in the latter borehole have a borehole-deviation correction of about $80 \mathrm{ft}$. The magnitude of this correction may be in error by as much as $10 \mathrm{ft}$ because the deviation survey is incomplete.

Water-level altitudes are used to represent the hydraulic head at each well opening. However, hydraulic head is dependent on the density (temperature and salinity) of the water. Wells in the study area that have a long (several thousand feet) water column (appendix 2) in combination with a warm water-column temperature (more than $10^{\circ} \mathrm{F}$ greater than typical ground-water temperatures of about $80^{\circ} \mathrm{F}$ ) could have a hydraulic head several feet lower than would be computed directly from the depth-to-water measurement. No attempt was made in this report to adjust water-level measurements for variations in water temperature because the potential error in the hydraulic head caused by these temperature differences is considered trivial given water-level contouring intervals of $50 \mathrm{ft}$ and greater. 


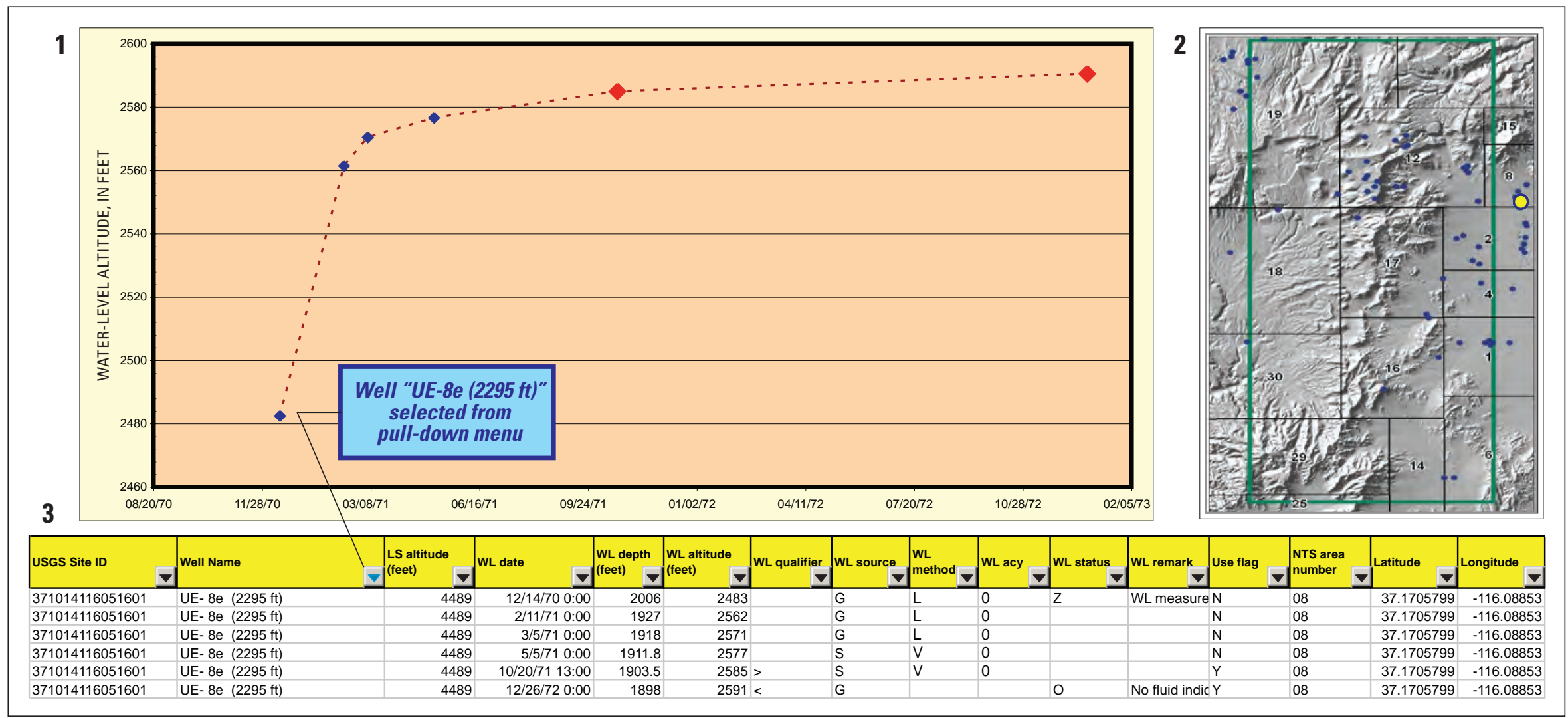

Figure 5. Example from appendix 1 Excel workbook showing water levels that were analyzed in well "UE-8e ( $2295 \mathrm{ft})$ ", Nevada Test Site, Nye County, Nevada. After a well is selected from pulldown menu, the worksheet is populated with (1) a hydrograph of all water-level measurements for the selected well—measurements used in contouring are shown as red diamonds; (2) a map showing the selected well location as a yellow circle; and (3) a table of water-level data for the selected well. 
Water levels from each well were evaluated further to determine if and which water levels represent predevelopment hydrologic conditions. Hydrograph trends were analyzed and water levels that were attributed to unnatural influences such as recent well construction, pumping, or nuclear testing were filtered from the datasets. Of the 172 wells analyzed for this study, 133 of the wells (table 1; appendix 2) from 73 boreholes (fig. 2) had at least one water level identified as being representative of predevelopment conditions.

A single estimate of the water-level altitude was used to represent predevelopment conditions in each of the 133 wells identified as having at least one predevelopment water level (table 1). For wells with multiple measurements, the mean of the predevelopment measurements was used as the predevelopment estimate. A synoptic set of waterlevel measurements for all wells in the study area would be preferable to using mean water levels but this is not possible because many wells previously measured no longer exist and current hydrologic conditions monitored by some existing wells no longer represent predevelopment conditions. The error associated with comparing water levels that span decades is assumed to be minor because long-term, naturally occurring, water-level fluctuations generally are less than $5 \mathrm{ft}$.
Water levels used to estimate the predevelopment altitude at each of the 133 wells listed in table 1 are shown as red circles on hydrographs that can be plotted interactively by using appendix 1 (fig. 5).

The predevelopment, water-level altitude estimate was determined from a single water-level measurement in 65 of the 133 wells. In about one-half of these 65 wells, the single measurement represents transient, non-equilibrium conditions and thus could only be used as an upper or lower bound for the predevelopment water level. For example, on a rising water-level hydrograph that has not yet reached equilibrium, the last water level can be used as a lower bound for the expected predevelopment, water-level altitude in the well. In this example, if the altitude of the last water-level measurement was $1,000 \mathrm{ft}$, the predevelopment, waterlevel altitude is expected to be greater than 1,000 ft. For measurements made in a dry well, the bottom-of-the-well altitude is assigned a "less than" qualifier and is used as an upper bound for contouring. Only mean water levels representing predevelopment conditions, or those that were assigned a "less than" or "greater than" qualifier to constrain the predevelopment level, were used to guide the contouring process.

Table 1. Water-level data and well characteristics for wells used to develop water-level contours in the Rainier Mesa and Shoshone Mountain area, Nevada Test Site, Nye County, Nevada.

[Latitudeand Longitude: In decimal degrees; referenced to NAD 83. Mean water-level altitude Average of all predevelopment water-level measurements in well that were considered to represent the subsurface hydrologic unit type(s) open to well. Open interval: Area of well open to aquifer and where, if saturated, ground water may enter well. Open interval consists of open borehole and (or) well screen, including gravel packs. Where multiple open intervals occur in a well, altitudes are the top of uppermost interval and bottom of lowermost interval. Subsurfacehydrologic unit types at well opening Subsurface hydrologic unit types occurring at saturated part of open interval: AAQ, alluvial aquifer; LCA, lower carbonate aquifer, SCU, siliceous confining unit; UCA, upper carbonate aquifer; VAQ, volcanic aquifer; VCM; volcanic composite unit; VCU, volcanic confining unit. Abbreviations NGVD 29, National Geodetic Vertical Datum of 1929. USGS, U.S. Geological Survey; <, less than; >, greater than, ft, feet. Note: See appendix 2 for a more detailed table]

\begin{tabular}{|c|c|c|c|c|c|c|c|c|}
\hline \multirow{3}{*}{ USGS well name } & \multirow{3}{*}{$\begin{array}{c}\text { USGS site } \\
\text { identification No. }\end{array}$} & \multirow{3}{*}{ Latitude } & \multirow{3}{*}{ Longitude } & \multicolumn{4}{|c|}{ Altitudes, in feet above NGVD 29} & \multirow{3}{*}{$\begin{array}{c}\text { Subsurface hydrologic } \\
\text { unit types at well } \\
\text { opening }\end{array}$} \\
\hline & & & & \multirow{2}{*}{$\begin{array}{c}\text { Mean } \\
\text { water- } \\
\text { level } \\
\text { altitude }\end{array}$} & \multirow{2}{*}{$\begin{array}{l}\text { Land- } \\
\text { surface } \\
\text { altitude }\end{array}$} & \multicolumn{2}{|c|}{ Open interval } & \\
\hline & & & & & & $\begin{array}{l}\text { Altitude } \\
\text { of top }\end{array}$ & $\begin{array}{l}\text { Altitude } \\
\text { of bottom }\end{array}$ & \\
\hline Dolomite Hill Hole & 371106116112701 & 37.18508 & 116.19164 & $<5,275$ & 6,399 & 6,375 & 5,199 & UCA \\
\hline ER-12-1 (1641-1846ft) & 371106116110401 & 37.18486 & 116.18509 & 4,290 & 5,817 & 4,176 & 3,971 & $\mathrm{SCU}$ \\
\hline ER-12-1 (1641-3414ft) & 371106116110407 & 37.18486 & 116.18509 & 4,274 & 5,817 & 4,176 & 2,375 & SCU, UCA \\
\hline ER-12-1 (1883-1940 ft) & 371106116110405 & 37.18486 & 116.18509 & 4,337 & 5,817 & 3,934 & 3,857 & $\mathrm{SCU}$ \\
\hline ER-12-1 (2449-2602 ft) & 371106116110404 & 37.18486 & 116.18509 & 4,383 & 5,817 & 3,368 & 3,215 & SCU \\
\hline ER-12-1 (2958-3212 ft) & 371106116110403 & 37.18486 & 116.18509 & 3,038 & 5,817 & 2,859 & 2,605 & UCA \\
\hline ER-12-1 (3309-3414ft) & 371106116110402 & 37.18486 & 116.18509 & 3,055 & 5,817 & 2,508 & 2,375 & UCA \\
\hline ER-12-1 (brhl) & 371106116110406 & 37.18486 & 116.18509 & 4,272 & 5,817 & 4,343 & 2,229 & SCU, UCA \\
\hline ER-12-2 main (lower zone) & 371019116072102 & 37.17148 & 116.12338 & $>4,525$ & 4,705 & -498 & $-2,178$ & $\mathrm{SCU}$ \\
\hline ER-12-2 main (upper zone) & 371019116072103 & 37.17148 & 116.12338 & $>4,525$ & 4,705 & 1,741 & -498 & $\mathrm{SCU}$ \\
\hline ER-12-2 piezometer & 371019116072104 & 37.17148 & 116.12338 & 4,289 & 4,705 & 4,585 & 4,055 & VAQ, VCU \\
\hline ER-12-3 main & 371142116125102 & 37.19497 & 116.21499 & 4,279 & 7,391 & 4,944 & 2,483 & UCA \\
\hline ER-12-3 piezometer & 371142116125101 & 37.19497 & 116.21499 & 6,146 & 7,391 & 7,336 & 5,181 & VCU, VAQ \\
\hline ER-12-4 main & 371311116105902 & 37.21958 & 116.18402 & 4,317 & 6,884 & 4,383 & 3,169 & UCA \\
\hline ER-12-4 piezometer & 371311116105901 & 37.21958 & 116.18402 & 5,967 & 6,884 & 6,828 & 4,896 & VAQ, VCU \\
\hline ER-16-1 (recompleted) & 370031116121103 & 37.00852 & 116.20397 & 2,501 & 6,592 & 2,586 & 2,026 & LCA \\
\hline ER-19-1-1 (deep) & 371043116142101 & 37.17847 & 116.24002 & 4,363 & 6,140 & 2,930 & 2,580 & SCU \\
\hline
\end{tabular}


Table 1. Water-level data and well characteristics for wells used to develop water-level contours in the Rainier Mesa and Shoshone Mountain area, Nevada Test Site, Nye County, Nevada.-Continued

[Latitudeand Longitude: In decimal degrees; referenced to NAD 83. Mœn water-level altitude: Average of all predevelopment water-level measurements in well that were considered to represent the subsurface hydrologic unit type(s) open to well. Open interval: Area of well open to aquifer and where, if saturated, ground water may enter well. Open interval consists of open borehole and (or) well screen, including gravel packs. Where multiple open intervals occur in a well, altitudes are the top of uppermost interval and bottom of lowermost interval. Subsurfacehydrologic unit types at well opening: Subsurface hydrologic unit types occurring at saturated part of open interval: AAQ, alluvial aquifer; LCA, lower carbonate aquifer, SCU, siliceous confining unit; UCA, upper carbonate aquifer; VAQ, volcanic aquifer; VCM; volcanic composite unit; VCU, volcanic confining unit. Abbreviations NGVD 29, National Geodetic Vertical Datum of 1929. USGS, U.S. Geological Survey; <, less than; >, greater than, ft, feet. Note: See appendix 2 for a more detailed table]

\begin{tabular}{|c|c|c|c|c|c|c|c|c|}
\hline \multirow{3}{*}{ USGS well name } & \multirow{3}{*}{$\begin{array}{c}\text { USGS site } \\
\text { identification No. }\end{array}$} & \multirow{3}{*}{ Latitude } & \multirow{3}{*}{ Longitude } & \multicolumn{4}{|c|}{ Altitudes, in feet above NGVD 29} & \multirow{3}{*}{$\begin{array}{c}\text { Subsurface hydrologic } \\
\text { unit types at well } \\
\text { opening }\end{array}$} \\
\hline & & & & \multirow{2}{*}{$\begin{array}{c}\text { Mean } \\
\text { water- } \\
\text { level } \\
\text { altitude }\end{array}$} & \multirow{2}{*}{$\begin{array}{l}\text { Land- } \\
\text { surface } \\
\text { altitude }\end{array}$} & \multicolumn{2}{|c|}{ Open interval } & \\
\hline & & & & & & $\begin{array}{l}\text { Altitude } \\
\text { of top }\end{array}$ & $\begin{array}{l}\text { Altitude } \\
\text { of bottom }\end{array}$ & \\
\hline ER-19-1-2 (middle) & 371043116142102 & 37.17847 & 116.24002 & 4,996 & 6,140 & 3,590 & 3,402 & VAQ, VCU \\
\hline ER-19-1-3 (shallow) & 371043116142103 & 37.17847 & 116.24002 & 5,134 & 6,140 & 4,839 & 4,718 & VCU \\
\hline ER-30-1-1 (deep) & 370301116185801 & 37.05021 & 116.31707 & 4,197 & 4,647 & 3,970 & 3,857 & VCM \\
\hline ER-30-1-2 (shallow) & 370301116185802 & 37.05021 & 116.31707 & 4,197 & 4,647 & 4,242 & 4,019 & VCM \\
\hline Hagestad 1 (1600-1904 ft) & 371131116125902 & 37.19199 & 116.21734 & 6,045 & 7,485 & 6,821 & 5,581 & VCU \\
\hline Hagestad $1(1874-1904 \mathrm{ft})$ & 371131116125901 & 37.19199 & 116.21734 & $<5,919$ & 7,485 & 6,821 & 5,581 & VCU \\
\hline TW- $1(0-560 \mathrm{ft})$ & 370929116132301 & 37.15813 & 116.2238 & 5,745 & 6,156 & 6,156 & 5,596 & VAQ \\
\hline TW- 1 (0-1615 ft) & 370929116132302 & 37.15813 & 116.2238 & 5,740 & 6,156 & 6,156 & 4,541 & VAQ, VCU \\
\hline TW- $1(0-3731 \mathrm{ft})$ & 370929116132305 & 37.15813 & 116.2238 & 5,129 & 6,156 & 6,156 & 2,425 & VAQ, VCU, UCA \\
\hline TW- 1 (1615-1840 ft) & 370929116132303 & 37.15813 & 116.2238 & 5,132 & 6,156 & 4,541 & 4,316 & $\mathrm{VCU}$ \\
\hline TW- $1(1615-3300 \mathrm{ft})$ & 370929116132307 & 37.15813 & 116.2238 & 4,715 & 6,156 & 4,541 & 2,856 & VCU, VAQ \\
\hline TW- 1 (1615-4206 ft) & 370929116132311 & 37.15813 & 116.2238 & 4,692 & 6,156 & 4,541 & 1,950 & VAQ, VCU, UCA \\
\hline TW- 1 (3700-3731 ft) & 370929116132304 & 37.15813 & 116.2238 & 4,172 & 6,156 & 2,456 & 2,425 & UCA \\
\hline TW- 1 (3700-4206 ft) & 370929116132309 & 37.15813 & 116.2238 & 4,191 & 6,156 & 2,456 & 1,950 & UCA \\
\hline $\mathrm{U}-2 \mathrm{ca} 1$ & 370822116082701 & 37.13951 & 116.14177 & $<3,545$ & 4,871 & 4,803 & 3,398 & VCU, UCA \\
\hline$U-2 c t$ & 370702116071901 & 37.11722 & 116.12268 & $<3,092$ & 4,509 & 4,389 & 3,009 & VAQ \\
\hline$U-2 c w$ & 370755116071901 & 37.13202 & 116.12295 & $<2,922$ & 4,532 & 4,412 & 2,692 & VCU \\
\hline $\mathrm{U}-2 \mathrm{dr}$ & 370802116050301 & 37.13396 & 116.08512 & 2,455 & 4,313 & 4,196 & 2,313 & AAQ \\
\hline $\mathrm{U}-2 \mathrm{eh}$ & 370900116045601 & 37.14983 & 116.08313 & $<2,470$ & 4,368 & 4,251 & 2,118 & AAQ, VAQ \\
\hline $\mathrm{U}-8 \mathrm{j}$ & 371048116052001 & 37.17993 & 116.08983 & $<2,689$ & 4,556 & 4,437 & 2,556 & VCU, LCA \\
\hline$U-8 n$ & 371031116053001 & 37.17527 & 116.09261 & $>2,770$ & 4,542 & 4,424 & 2,649 & VCU \\
\hline $\mathrm{U}-12 \mathrm{e} .03-1(682 \mathrm{ft})$ & 371122116122202 & 37.1894 & 116.20693 & $<5,666$ & 7,545 & 5,672 & 5,468 & VCU \\
\hline $\mathrm{U}-12 \mathrm{e} .03-1(834 \mathrm{ft})$ & 371122116122203 & 37.1894 & 116.20693 & $<5,440$ & 7,545 & 5,449 & 5,316 & VCU, UCA \\
\hline $\mathrm{U}-12 \mathrm{e} .06-1 \mathrm{R} / \mathrm{C}$ & 371052116125201 & 37.18098 & 116.2152 & $<4,642$ & 7,573 & 7,573 & 4,393 & UCA \\
\hline U -12e.M1 UG (1501ft) & 371106116123001 & 37.18496 & 116.20915 & $<4,674$ & 7,539 & 5,305 & 4,658 & UCA \\
\hline U -12e.M1 UG (19ft) & 371106116123002 & 37.18496 & 116.20915 & $>6,160$ & 7,539 & 6,150 & 6,140 & VCU \\
\hline U -12e.M1 UG $(631 \mathrm{ft})$ & 371106116123003 & 37.18496 & 116.20915 & $>6,185$ & 7,539 & 6,150 & 5,528 & VCU \\
\hline U -12e.M1 UG (777ft) & 371106116123004 & 37.18496 & 116.20915 & 6,105 & 7,539 & 6,150 & 5,382 & VCU \\
\hline U -12g.06 PS 1V & 371028116123002 & 37.17438 & 116.20927 & $<6,154$ & 7,626 & 6,800 & 6,152 & VCU \\
\hline$U-12 q$ & 371153116134601 & 37.19813 & 116.23039 & 5,600 & 7,413 & 7,407 & 5,269 & VCU \\
\hline $\mathrm{U}-12 \mathrm{~s}(1480 \mathrm{ft})$ & 371342116125102 & 37.22829 & 116.21669 & 5,857 & 6,794 & 6,782 & 5,314 & SCU \\
\hline $\mathrm{U}-12 \mathrm{~s}(1596 \mathrm{ft})$ & 371342116125101 & 37.22829 & 116.21669 & $>5,828$ & 6,794 & 6,782 & 5,198 & SCU \\
\hline $\mathrm{U}-12 \mathrm{t} .04 \mathrm{CH} 1$ & 371316116105001 & 37.2212 & 116.18142 & 5,912 & 6,796 & 6,736 & 5,609 & VCU \\
\hline $\mathrm{U}-19 \mathrm{ab}$ & 371512116193101 & 37.25335 & 116.32609 & 4,905 & 6,928 & 6,870 & 4,678 & VCU \\
\hline $\mathrm{U}-19 \mathrm{ab} 2$ & 371513116193001 & 37.25346 & 116.32585 & 4,915 & 6,930 & 6,868 & 4,530 & VCU \\
\hline $\mathrm{U}-19 \mathrm{ac}$ & 371653116181901 & 37.28131 & 116.3063 & $<4,744$ & 7,038 & 6,980 & 4,738 & VAQ \\
\hline U -19aj & 371812116193201 & 37.30334 & 116.32648 & 4,700 & 6,891 & 6,831 & 4,691 & VCU \\
\hline $\mathrm{U}-19 \mathrm{ax}$ & 371750116182401 & 37.2971 & 116.30742 & $<4,816$ & 6,986 & 6,926 & 4,786 & VCU \\
\hline $\mathrm{U}-19 \mathrm{ba}$ & 371746116184601 & 37.29603 & 116.31379 & 4,884 & 7,037 & 6,967 & 4,857 & VAQ, VCU \\
\hline $\mathrm{U}-19 \mathrm{ba} 1$ & 371746116184701 & 37.2961 & 116.31386 & $<4,694$ & 7,038 & 6,973 & 4,698 & VCU \\
\hline $\mathrm{U}-19 \mathrm{ba} 2$ & 371745116184701 & 37.29592 & 116.31397 & $<4,699$ & 7,039 & 6,975 & 4,699 & VCU \\
\hline $\mathrm{U}-19$ ba 3 & 371746116184702 & 37.29623 & 116.31397 & $<4,728$ & 7,038 & 6,978 & 4,698 & VCU \\
\hline $\mathrm{U}-19 \mathrm{bj}$ & 371736116184701 & 37.29315 & 116.3138 & 4,899 & 7,034 & 6,978 & 4,882 & VAQ \\
\hline $\mathrm{U}-19 \mathrm{c}(2656 \mathrm{ft})$ & 371554116185303 & 37.26486 & 116.31553 & 4,692 & 7,032 & 7,020 & 4,376 & VAQ, VCU \\
\hline
\end{tabular}


Table 1. Water-level data and well characteristics for wells used to develop water-level contours in the Rainier Mesa and Shoshone Mountain area, Nevada Test Site, Nye County, Nevada.-Continued

[Latitudeand Longitude: In decimal degrees; referenced to NAD 83. Meen water-level altitude Average of all predevelopment water-level measurements in well that were considered to represent the subsurface hydrologic unit type(s) open to well. Open interval: Area of well open to aquifer and where, if saturated, ground water may enter well. Open interval consists of open borehole and (or) well screen, including gravel packs. Where multiple open intervals occur in a well, altitudes are the top of uppermost interval and bottom of lowermost interval. Subsurfacehydrologic unit types at well opening: Subsurface hydrologic unit types occurring at saturated part of open interval: AAQ, alluvial aquifer; LCA, lower carbonate aquifer, SCU, siliceous confining unit; UCA, upper carbonate aquifer; VAQ, volcanic aquifer; VCM; volcanic composite unit; VCU, volcanic confining unit. Abloreviations NGVD 29, National Geodetic Vertical Datum of 1929. USGS, U.S. Geological Survey; <, less than; >, greater than, ft, feet. Note: See appendix 2 for a more detailed table]

\begin{tabular}{|c|c|c|c|c|c|c|c|c|}
\hline \multirow{3}{*}{ USGS well name } & \multirow{3}{*}{$\begin{array}{c}\text { USGS site } \\
\text { identification No. }\end{array}$} & \multirow{3}{*}{ Latitude } & \multirow{3}{*}{ Longitude } & \multicolumn{4}{|c|}{ Altitudes, in feet above NGVD 29} & \multirow{3}{*}{$\begin{array}{c}\text { Subsurface hydrologic } \\
\text { unit types at well } \\
\text { opening }\end{array}$} \\
\hline & & & & \multirow{2}{*}{$\begin{array}{c}\text { Mean } \\
\text { water- } \\
\text { level } \\
\text { altitude }\end{array}$} & \multirow{2}{*}{$\begin{array}{l}\text { Land- } \\
\text { surface } \\
\text { altitude }\end{array}$} & \multicolumn{2}{|c|}{ Open interval } & \\
\hline & & & & & & $\begin{array}{l}\text { Altitude } \\
\text { of top }\end{array}$ & $\begin{array}{l}\text { Altitude } \\
\text { of bottom }\end{array}$ & \\
\hline $\mathrm{U}-19 \mathrm{e}(4410-4840 \mathrm{ft})$ & 371748116195903 & 37.2965 & 116.33407 & $<4,640$ & 6,919 & 2,509 & 2,079 & VAQ \\
\hline $\mathrm{U}-19 \mathrm{e}(4504-4572 \mathrm{ft})$ & 371748116195908 & 37.2965 & 116.33407 & $\begin{array}{l}>4,595 ; \\
<4,621\end{array}$ & 6,919 & 2,415 & 2,347 & VAQ \\
\hline $\mathrm{U}-19 \mathrm{e}(5050 \mathrm{ft})$ & 371748116195901 & 37.2965 & 116.33407 & 4,695 & 6,919 & 6,907 & 1,869 & VAQ, VCU \\
\hline UE- 1a & 370254116070601 & 37.04823 & 116.11927 & 3,758 & 4,304 & 4,226 & 3,347 & VAQ, SCU \\
\hline UE- $1 b$ & 370254116064201 & 37.0482 & 116.11242 & 3,629 & 4,273 & 4,197 & 3,019 & VAQ, SCU \\
\hline UE- $1 c$ & 370253116055201 & 37.04813 & 116.09871 & 2,909 & 4,207 & 4,133 & 2,327 & VAQ, VCU, UCA, LCA \\
\hline UE- $1 d$ & 370301116065301 & 37.05013 & 116.11566 & 3,760 & 4,296 & 4,217 & 3,439 & AAQ, VAQ, VCU, SCU \\
\hline UE- $1 f$ & 370246116064901 & 37.04604 & 116.11458 & 3,649 & 4,277 & 4,218 & 3,574 & SCU \\
\hline UE- 1L (recompleted) & 370254116082002 & 37.04832 & 116.13983 & 3,938 & 4,457 & 3,741 & 2,173 & SCU \\
\hline UE- $2 \mathrm{ax} 2$ & 370910116045901 & 37.15259 & 116.08393 & 2,428 & 4,396 & 4,324 & 1,946 & AAQ, VAQ, VCU, \\
\hline UE- $2 b$ & 370748116051201 & 37.12999 & 116.08744 & 2,422 & 4,310 & 4,190 & 798 & VAQ, VCU, LCA \\
\hline UE- 2ce & 370831116080701 & 37.14197 & 116.13609 & $<3,315$ & 4,765 & 3,388 & 3,115 & $\mathrm{UCA}$ \\
\hline UE- 2dj & 370823116050001 & 37.1398 & 116.0843 & 2,446 & 4,341 & 4,264 & 1,991 & AAQ VAQ \\
\hline UE- $2 \mathrm{fb}$ & 370736116050301 & 37.12662 & 116.08492 & 2,505 & 4,274 & 4,191 & 1,484 & VAQ, VCU, LCA \\
\hline UE- $2 s$ & 370712116073901 & 37.11982 & 116.12847 & $<2,640$ & 4,583 & 3,533 & 2,613 & $\mathrm{UCA}$ \\
\hline UE- 4aa & 370543116054101 & 37.0952 & 116.09564 & $<3,099$ & 4,254 & 4,178 & 3,030 & UCA \\
\hline UE- 4ac (1677 ft) & 370601116071401 & 37.10028 & 116.12147 & $<2,921$ & 4,471 & 4,397 & 2,804 & VCU \\
\hline UE- 8e (2295 ft) & 371014116051601 & 37.17058 & 116.08852 & $\begin{array}{l}>2,585 \\
<2,590\end{array}$ & 4,488 & 4,418 & 2,368 & VCU \\
\hline UE- $8 \mathrm{e}(2470 \mathrm{ft})$ & 371014116051602 & 37.17058 & 116.08852 & 2,578 & 4,488 & 4,418 & 2,018 & VCU, LCA \\
\hline UE-10j (2232-2297ft) & 371108116045303 & 37.18548 & 116.08239 & 2,417 & 4,574 & 2,342 & 2,277 & LCA \\
\hline UE-10j (2232-2613 ft) & 371108116045302 & 37.18548 & 116.08239 & 2,416 & 4,574 & 2,342 & 1,961 & LCA \\
\hline UE-10j $(2380 \mathrm{ft})$ & 371108116045301 & 37.18548 & 116.08239 & 2,414 & 4,574 & 4,519 & 2,194 & LCA \\
\hline UE-12n $15 \mathrm{~A}$ & 371226116125201 & 37.20725 & 116.21538 & 6,039 & 7,369 & 6,669 & 5,435 & VCU, SCU \\
\hline UE-12t 6 (1378 ft) & 371332116112801 & 37.22543 & 116.19207 & $<6,040$ & 6,907 & 6,884 & 5,529 & VCU \\
\hline UE-12t $6(1461 \mathrm{ft})$ & 371332116112802 & 37.22543 & 116.19207 & 6,072 & 6,907 & 6,884 & 5,446 & VCU, SCU \\
\hline UE-12t 7 & 371307116103801 & 37.22952 & 116.18267 & 6,121 & 6,961 & 6,941 & 5,269 & VCU, SCU \\
\hline UE-14a & 365550116084201 & 36.9305 & 116.14577 & 2,693 & 4,339 & 4,259 & 1,039 & VAQ, VCU \\
\hline UE-14b & 365550116091101 & 36.93054 & 116.15395 & 2,687 & 4,353 & 2,302 & 673 & VAQ, VCU \\
\hline UE-16d WW & 370412116095101 & 37.07006 & 116.16516 & 3,931 & 4,684 & 4,603 & 2,740 & UCA, SCU \\
\hline UE-16d WW (830 ft) & 370406116095600 & 37.07006 & 116.16516 & 3,931 & 4,684 & 4,603 & 3,854 & $\mathrm{UCA}$ \\
\hline UE-16d WW (2117-2293 ft) & 370412116095102 & 37.07006 & 116.16516 & 4,093 & 4,684 & 2,567 & 2,391 & SCU \\
\hline $\mathrm{UE}-16 \mathrm{f}(1479 \mathrm{ft})$ & 370208116092402 & 37.03563 & 116.15759 & 4,284 & 4,651 & 3,358 & 3,172 & $\mathrm{SCU}$ \\
\hline UE-17a & 370425116095801 & 37.07353 & 116.16711 & $>4,073$ & 4,696 & 3,952 & 3,482 & SCU \\
\hline UE-17c & 370616116090801 & 37.10453 & 116.153 & $<4,323$ & 4,835 & 4,797 & 4,249 & UCA \\
\hline $\mathrm{UE}-18 \mathrm{t}$ & 370741116194501 & 37.12809 & 116.33003 & 4,286 & 5,201 & 5,081 & 2,601 & VCM \\
\hline UE-19b 1 (2190-2374 ft) & 371852116175708 & 37.31453 & 116.30017 & 4,677 & 6,802 & 4,612 & 4,428 & VAQ \\
\hline UE-19b 1 (2361-2559ft) & 371852116175707 & 37.31453 & 116.30017 & 4,677 & 6,802 & 4,441 & 4,243 & VAQ \\
\hline UE-19b 1 (2556-2754 ft) & 371852116175706 & 37.31453 & 116.30017 & 4,677 & 6,802 & 4,246 & 4,048 & VAQ \\
\hline UE-19b 1 (2754-2952 ft) & 371852116175705 & 37.31453 & 116.30017 & $<4,685$ & 6,802 & 4,048 & 3,850 & VAQ \\
\hline UE-19b 1 (3758-3956 ft) & 371852116175702 & 37.31453 & 116.30017 & $<4,682$ & 6,802 & 3,044 & 2,846 & VAQ \\
\hline UE-19b 1 WW & 371852116175701 & 37.31453 & 116.30017 & 4,685 & 6,802 & 4,612 & 2,302 & VAQ \\
\hline UE-19c (2421-2884ft) & 371608116191010 & 37.26872 & 116.32036 & $>4,714$ & 7,033 & 4,612 & 4,149 & VAQ \\
\hline UE-19c (2421-4520 ft) & 371608116191001 & 37.26872 & 116.32036 & 4,685 & 7,033 & 4,612 & 2,513 & VAQ \\
\hline
\end{tabular}


Table 1. Water-level data and well characteristics for wells used to develop water-level contours in the Rainier Mesa and Shoshone Mountain area, Nevada Test Site, Nye County, Nevada.-Continued

[Latitudeand Longitude: In decimal degrees; referenced to NAD 83. Møn water-level altitude: Average of all predevelopment water-level measurements in well that were considered to represent the subsurface hydrologic unit type(s) open to well. Open interval: Area of well open to aquifer and where, if saturated, ground water may enter well. Open interval consists of open borehole and (or) well screen, including gravel packs. Where multiple open intervals occur in a well, altitudes are the top of uppermost interval and bottom of lowermost interval. Subsurfacehydrologic unit types at well opening: Subsurface hydrologic unit types occurring at saturated part of open interval: AAQ, alluvial aquifer; LCA, lower carbonate aquifer, SCU, siliceous confining unit; UCA, upper carbonate aquifer; VAQ, volcanic aquifer; VCM; volcanic composite unit; VCU, volcanic confining unit. Abbreviations NGVD 29, National Geodetic Vertical Datum of 1929. USGS, U.S. Geological Survey; <, less than; >, greater than, ft, feet. Note: See appendix 2 for a more detailed table]

\begin{tabular}{|c|c|c|c|c|c|c|c|c|}
\hline \multirow{3}{*}{ USGS well name } & \multirow{3}{*}{$\begin{array}{c}\text { USGS site } \\
\text { identification No. }\end{array}$} & \multirow{3}{*}{ Latitude } & \multirow{3}{*}{ Longitude } & \multicolumn{4}{|c|}{ Altitudes, in feet above NGVD 29} & \multirow{3}{*}{$\begin{array}{c}\text { Subsurface hydrologic } \\
\text { unit types at well } \\
\text { opening }\end{array}$} \\
\hline & & & & \multirow{2}{*}{$\begin{array}{c}\text { Mean } \\
\text { water- } \\
\text { level } \\
\text { altitude }\end{array}$} & \multirow{2}{*}{$\begin{array}{l}\text { Land- } \\
\text { surface } \\
\text { altitude }\end{array}$} & \multicolumn{2}{|c|}{ Open interval } & \\
\hline & & & & & & $\begin{array}{l}\text { Altitude } \\
\text { of top }\end{array}$ & $\begin{array}{l}\text { Altitude } \\
\text { of bottom }\end{array}$ & \\
\hline$\overline{\mathrm{UE}-19 \mathrm{c}(2884-3082 \mathrm{ft})}$ & 371608116191009 & 37.26872 & 116.32036 & 4,685 & 7,033 & 4,149 & 3,951 & VAQ \\
\hline UE-19c (3078-3284ft) & 371608116191008 & 37.26872 & 116.32036 & 4,685 & 7,033 & 3,955 & 3,749 & VAQ \\
\hline UE-19c (4025-4235 ft) & 371608116191005 & 37.26872 & 116.32036 & $<4,672$ & 7,033 & 3,008 & 2,798 & VAQ \\
\hline UE-19c (4266-4520 ft) & 371608116191003 & 37.26872 & 116.32036 & 4,673 & 7,033 & 2,767 & 2,513 & VAQ \\
\hline UE-19c WW & 371608116191002 & 37.26872 & 116.32036 & 4,694 & 7,033 & 4,612 & $-1,456$ & VAQ, VCM \\
\hline UE-19e (2619-2779ft) & 371750116195918 & 37.29705 & 116.33407 & 4,686 & 6,919 & 4,300 & 4,140 & VCU \\
\hline UE-19e (4802-5000 ft) & 371750116195904 & 37.29705 & 116.33407 & 4,666 & 6,919 & 2,117 & 1,919 & VAQ \\
\hline UE-19e (5004-6004 ft) & 371750116195903 & 37.29705 & 116.33407 & 4,667 & 6,919 & 1,915 & 915 & VAQ \\
\hline UE-19e WW & 371750116195901 & 37.29705 & 116.33407 & 4,701 & 6,919 & 4,444 & 914 & VAQ, VCU \\
\hline UE-19z (2225 ft) & 371758116193602 & 37.29947 & 116.32768 & $>4,786$ & 6,888 & 6,802 & 4,663 & VCU \\
\hline UE-19z (2800 ft) & 371758116193601 & 37.29947 & 116.32768 & 4,690 & 6,888 & 6,802 & 4,088 & VCU \\
\hline USGS - Shot Hole & 371205116080201 & 37.20128 & 116.13465 & 4,978 & 5,065 & 5,065 & 4,960 & AAQ \\
\hline Whiterock Springs 1 & 371204116075501 & 37.201 & 116.13293 & 5,044 & 5,065 & 5,063 & 4,993 & VCU \\
\hline Whiterock Springs 2 & 371210116075001 & 37.20265 & 116.13155 & 5,030 & 5,080 & 5,080 & 4,996 & VCU \\
\hline Whiterock Springs 3 & 371158116075501 & 37.19935 & 116.13294 & 5,022 & 5,030 & 5,030 & 4,989 & VCU \\
\hline Whiterock Springs 4 & 371148116074801 & 37.1966 & 116.1309 & 4,910 & 4,959 & 4,959 & 4,888 & VCU \\
\hline WW- $2(2045 \mathrm{ft})$ & 370958116051501 & 37.16619 & 116.08849 & 2,555 & 4,470 & 3,005 & 2,425 & $\mathrm{VCU}$ \\
\hline WW- $2(2535 \mathrm{ft})$ & 370958116051503 & 37.16619 & 116.08849 & $<2,490$ & 4,470 & 2,349 & 1,935 & VCU, LCA \\
\hline WW- 2 (2896ft) & 370958116051508 & 37.16619 & 116.08849 & 2,414 & 4,470 & 1,920 & 1,574 & LCA \\
\hline WW- $2(3422 \mathrm{ft})$ & 370958116051512 & 37.16619 & 116.08849 & 2,417 & 4,470 & 1,770 & 1,058 & LCA \\
\hline WW- 2 (3422 ft, uncased) & 370958116051511 & 37.16619 & 116.08849 & 2,417 & 4,470 & 1,920 & 1,048 & LCA \\
\hline WW- $8(1770-2031 \mathrm{ft})$ & 370956116172102 & 37.16554 & 116.29003 & 4,624 & 5,695 & 3,925 & 3,664 & VAQ, VCU \\
\hline WW- 8 (2031-2053 ft) & 370956116172105 & 37.16554 & 116.29003 & 4,627 & 5,695 & 3,664 & 3,642 & $\mathrm{VCU}$ \\
\hline WW- 8 (2053-2249 ft) & 370956116172104 & 37.16554 & 116.29003 & 4,625 & 5,695 & 3,642 & 3,446 & VCU \\
\hline WW- $8(30-1198 \mathrm{ft})$ & 370956116172103 & 37.16554 & 116.29003 & 4,625 & 5,695 & 5,665 & 4,497 & VAQ \\
\hline WW- 8 (30-1935 ft) & 370956116172101 & 37.16554 & 116.29003 & 4,627 & 5,695 & 5,665 & 3,664 & VAQ, VCU \\
\hline WW- $8(3333-3429 \mathrm{ft})$ & 370956116172106 & 37.16554 & 116.29003 & 4,619 & 5,695 & 2,362 & 2,266 & VAQ \\
\hline WW- $8(3428-3524 \mathrm{ft})$ & 370956116172107 & 37.16554 & 116.29003 & 4,618 & 5,695 & 2,267 & 2,171 & VAQ \\
\hline WW- 8 (5290-5490 ft) & 370956116172108 & 37.16554 & 116.29003 & $\begin{array}{l}>4,274 \\
<4,309\end{array}$ & 5,695 & 405 & 205 & VCU \\
\hline
\end{tabular}

The predevelopment water-level altitude estimate for each well was assigned to a subsurface hydrologic unit type (SHUT). The assignment is made in accordance with the SHUT encountered at the open interval (table 1). Wells with long open intervals commonly penetrate multiple SHUTs. In these cases, water levels generally were associated with the most transmissive SHUT. The top and bottom SHUT altitudes at each well location were determined from the HFMs, which, in general, are in good agreement with well logs. The value of using the HFM in assigning the contributing SHUT is that it provides a consistent method for assigning SHUTS to water levels across the entire study area, regardless of whether or not a log or other lithologic information exists.
The HSUs and corresponding SHUTs for wells having predevelopment water-level altitudes can be displayed interactively from a Microsoft ${ }^{\circledR}$ Excel workbook (appendix 3 ). The workbook is designed to view the HFM-interpreted, stratigraphic column, the predevelopment water-level altitude, and basic well-construction information for wells in the study area. Information for an individual well can be viewed by selecting the well from the column-header dropdown list. An example workbook page for well "UE-8e (2295 ft)" is shown in figure 6. 


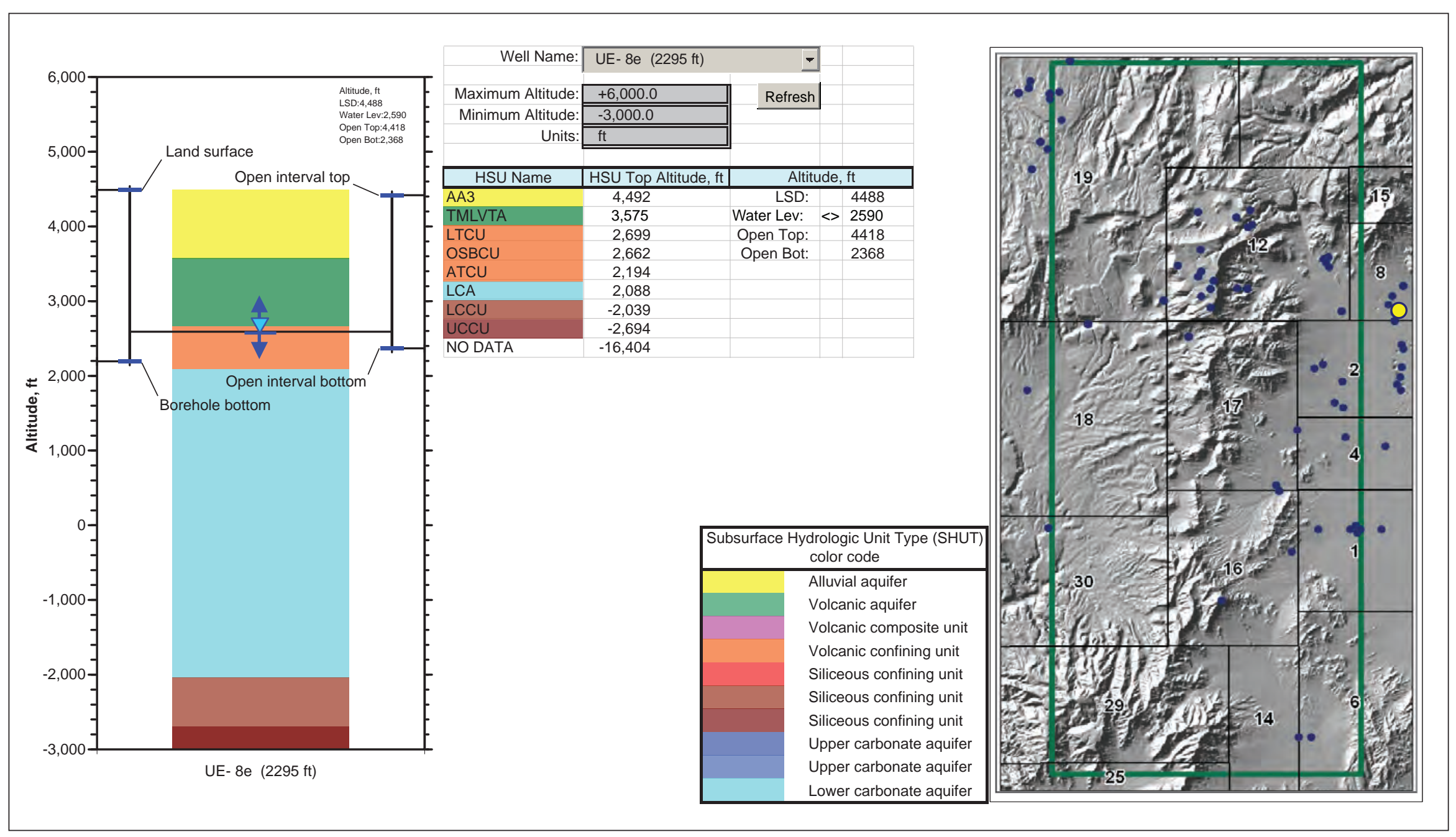

Figure 6. Example from appendix 3 Excel workbook showing hydrostratigraphic units and their relation to water level and open intervals in well "UE-8e (2295 $\mathrm{ft})$ ", Nevada Test Site, Nye County, Nevada. 
Each estimate of the predevelopment water-level altitude is assigned a single qualifier that describes how the estimate was used in the water-level contouring process (appendix 2). The five descriptive qualifiers describe the water level as:

- representative of the assigned SHUT;

- representative of multiple SHUTs;

- representative of an isolated aquifer;

- elevated relative to the regional water level; or

- depressed relative to the regional water level.

In cases where the direction of the vertical hydraulic gradient is known, a water level from a well open to a confining unit was used to constrain contours in an overlying or underlying aquifer, and consequently, is assigned to the aquifer but given a "less than" or "greater than" qualifier. For example, at a location with a known downward vertical hydraulic gradient, a predevelopment water-level altitude measured in a well open to the volcanic confining unit is assigned to the underlying volcanic aquifer with a "less than" qualifier. Remarks stating the relevance of each predevelopment water level as used in the contouring process are documented in appendix 2.

The configuration and extent of continuous and isolated aquifers within each of the three aquifer types were based on the distribution and lateral and vertical extent of its component SHUTS. The magnitudes of water-level differences between wells in the same aquifer type were used to help evaluate aquifer continuity. For example, where the continuity between two areas of the same aquifer type was in question, the similarity or difference in the water level was used to support or refute a hydraulic connection.

Water levels in each of the mapped continuous aquifers were contoured manually. Only rarely were water-level contours inconsistent with local well data. Any discrepancy between contours and data typically were minor (less than 5 $\mathrm{ft}$ ) and often the result of differences in water levels measured in closely spaced wells. In most cases, the inconsistency between measured and contoured water levels can be attributed to local vertical hydraulic gradients, unrecognized hydrologic anomalies, or small measurement errors. The manual contouring process took into consideration waterlevel gradients, recharge areas, discharge areas, and lateral and vertical continuity of flow systems (Blankennagel and Weir, 1973; Winograd and Thordarson, 1975; Laczniak and others, 1996; Belcher and others, 2004). Lastly, the contoured surfaces of the continuous aquifers were used to delineate tributary and regional flow systems.

\section{Water-Level Contours}

Water-level contours are presented for each continuous aquifer to portray the predevelopment, hydraulic gradients that influence the rate and direction of ground-water flow and potentially the transport of test-generated contaminants away from areas of underground testing in the RMSM area. Contours are interpreted from water levels measured in wells located throughout the study and surrounding areas. The contour maps represent the upper part of the aquifer, which is the area of the aquifer most likely to receive testgenerated contaminants from the overlying test media. This conceptualization assumes that transport from tests detonated in the tunnel complexes moves resident water downward and outward away from the low-permeability test media. On the basis of this assumption, contaminants introduced near Rainier Mesa would first encounter more-permeable saturated rock in the upper part of upper carbonate or volcanic aquifers, and any contaminants introduced into Shoshone Mountain would first encounter more-permeable saturated rock in the upper part of the lower carbonate aquifer.

The general direction of ground-water flow within each continuous aquifer, as indicated by interpreted contours, is shown with generalized flow arrows. Regional ground-water flow throughout the RMSM area and flow between continuous aquifers is described in terms of tributary flow systems, which combine flow paths of continuous aquifers. These intermediate flow paths can cross aquifer boundaries and are indicative of the most likely transport path from the source area toward major discharge areas. Because transient groundwater effects in the study area (for example, from pumping or nuclear testing) are short term and highly localized, the predevelopment flow paths depicted in this report also are assumed to closely approximate modern-day (1950-present) conditions.

\section{Volcanic Aquifer}

Permeable volcanic rocks are well connected hydraulically throughout the western part of the study area and together form a continuous volcanic aquifer that spans much of the western half of the study area. This aquifer constitutes one of the principal aquifers in the study area and is referred to in this report as the Pahute Mesa-Timber Mountain (PMTM) volcanic aquifer (section $B-B^{\prime}$ of fig. 7; fig. 8). In the eastern half of the study area, saturated permeable volcanic rocks are less continuous and more poorly connected hydraulically. These disconnected volcanic rocks form a few scattered volcanic aquifers that typically occur beneath the larger topographic valleys. These isolated aquifers typically are separated hydraulically from each other by the volcanic confining unit (fig. 7). 

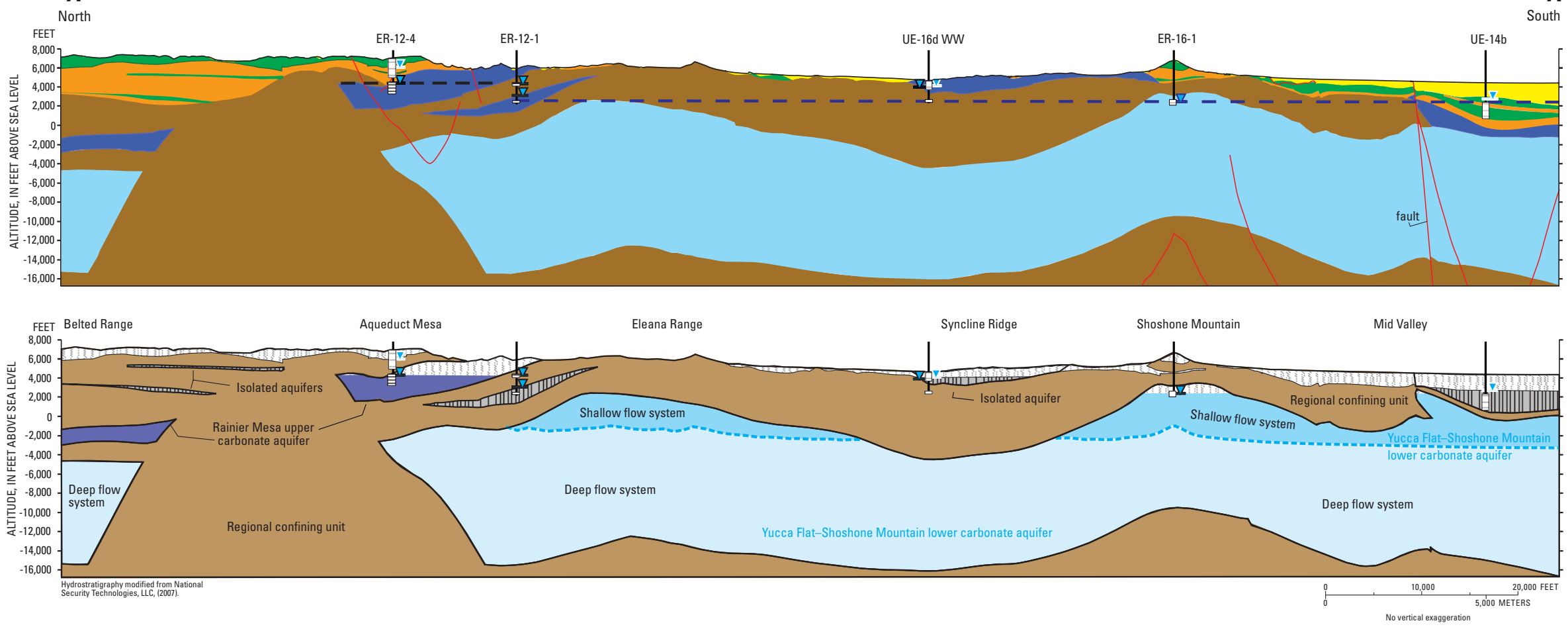

\section{EXPLANATION}
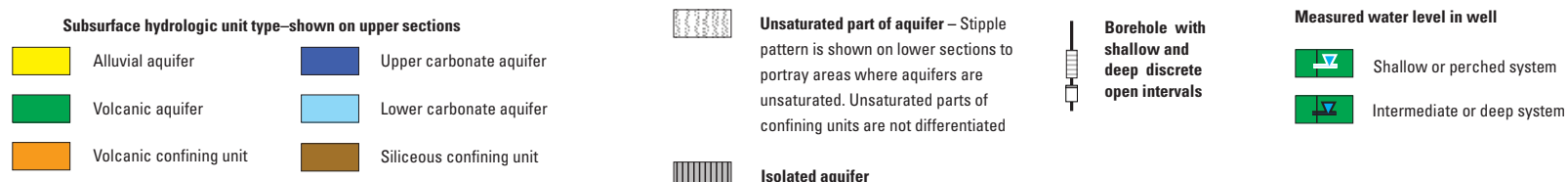

Water-level surface portray areas where aquifers are confining units are not differentiated

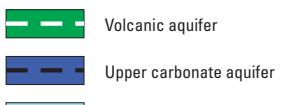

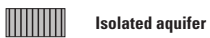

Figure 7. North-south and west-east sections through the Rainier Mesa and Shoshone Mountain area, Nevada Test Site, Nye County, Nevada showing distribution of subsurface hydrologic unit types (upper sections) and designations of continuous and isolated aquifers (lower sections). Trace of sections shown in figure 2. 


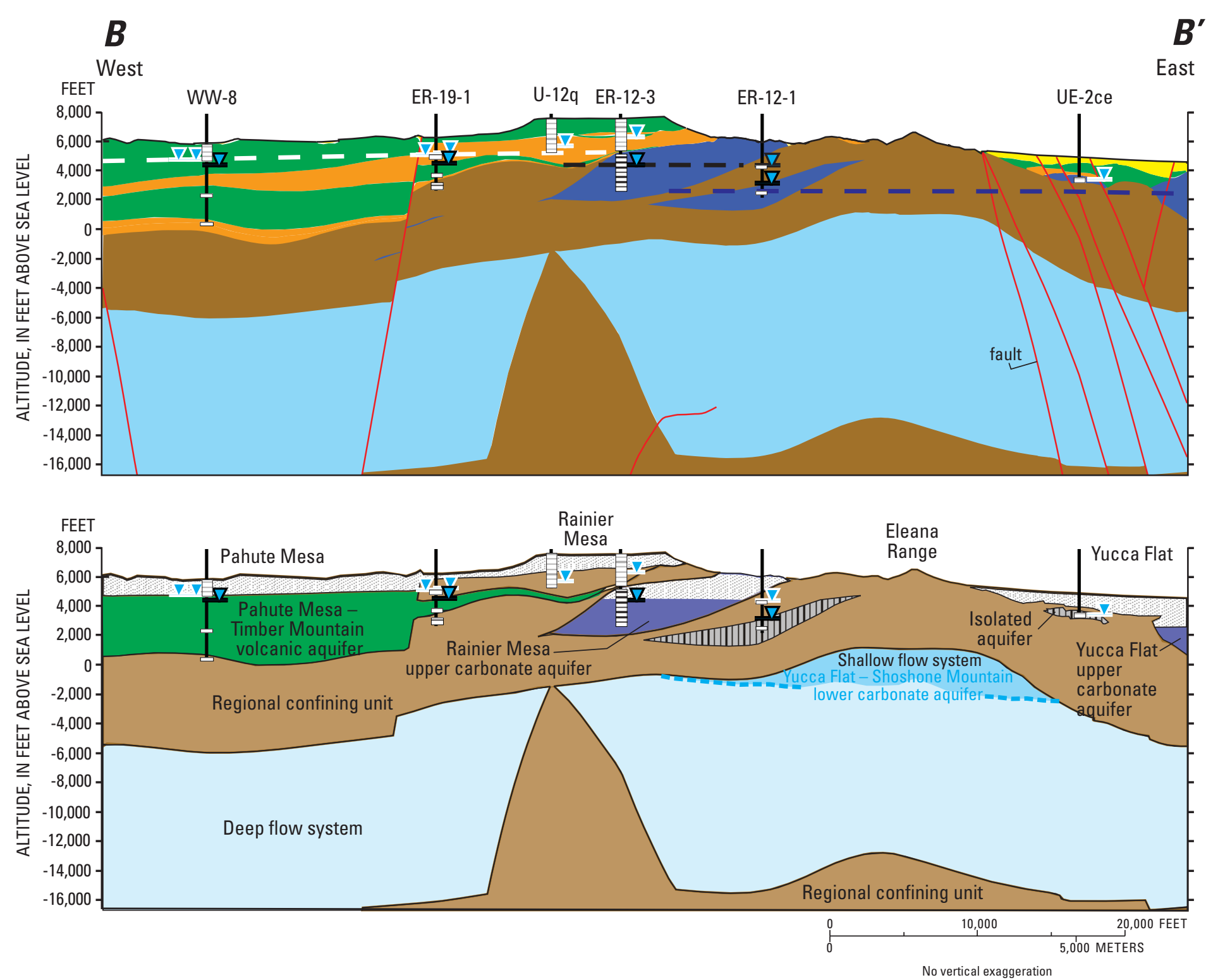

Figure 7.-Continued. 


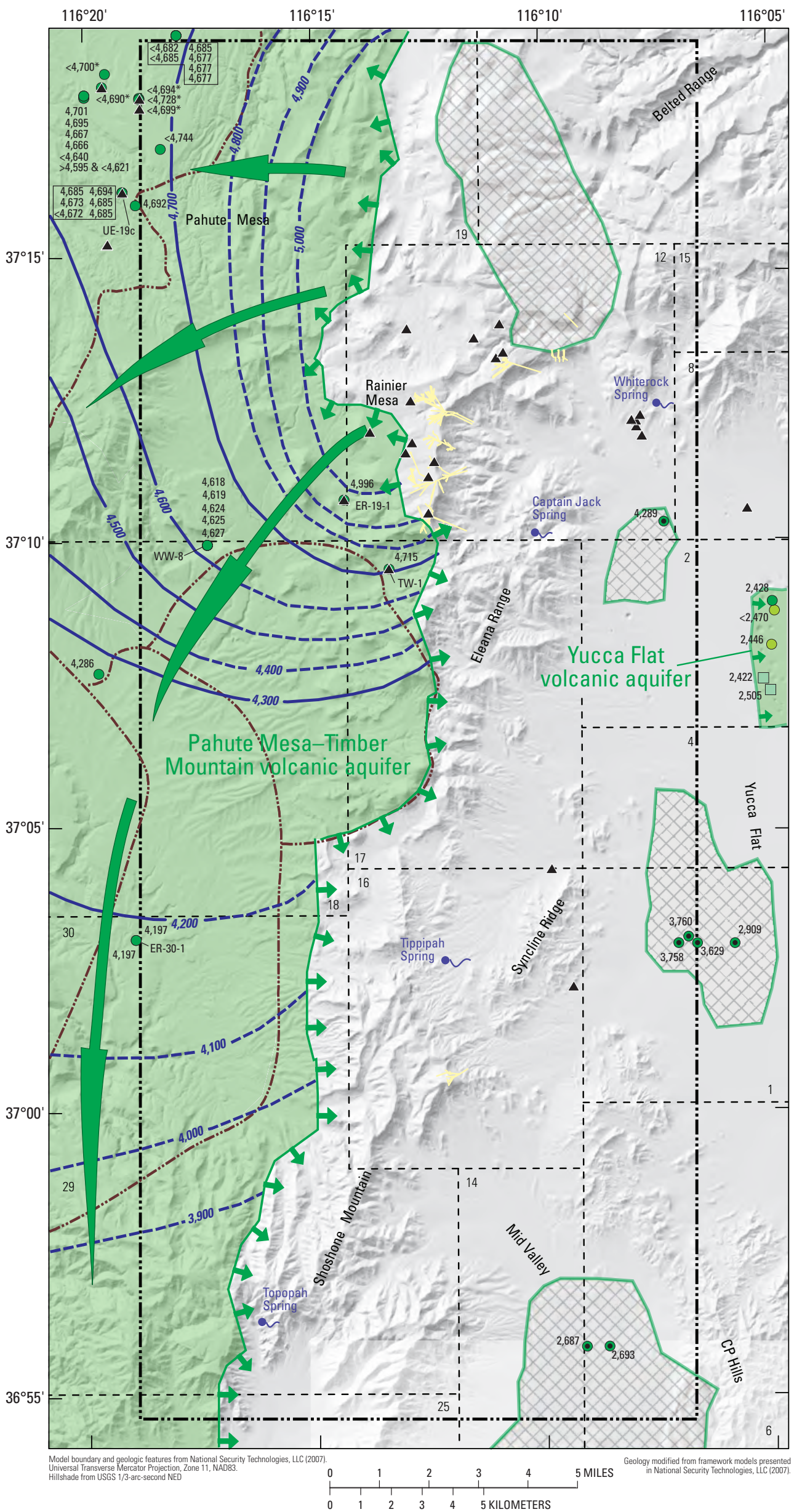

EXPLANATION

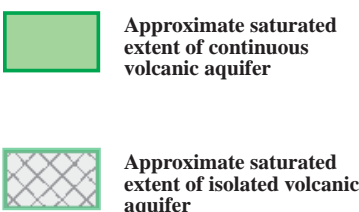
quifer

Tunnel complex

-..- Framework model boundary Caldera boundary

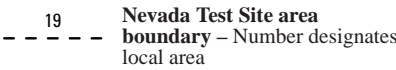

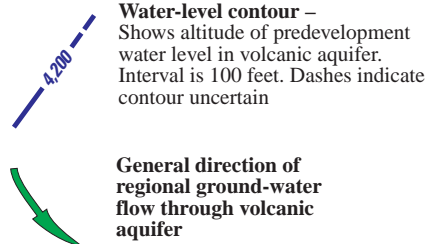

$\Rightarrow$ General direction of groundwater flow into and out of

Water-level altitude and measurement location - Shows well location and altitude used to develop contours of water-level altitude in continuous aquifer. Number is water-level altitude, in feet, at symbol location, and represents a predevelopment water level or mean of predevelopment levels measured in well:

$>$ indicates altitude is a minimum;

$<$ indicates altitude is a maximum; and

* indicates altitude for volcanic aquifer

confining unit (see appendix 2) Borehole name discussed in text is labeled; names not discussed are in figure 2

4,500 Well open to volcanic aquifer

4,500 Well open to volcanic aquifer 0 and alluvial aquifer

2,450 Well open to volcanic aquifer volcanic confining unit, an lower carbonate aquifer. Altitude typically depressed

4,500 Well open to isolated volcanic aquifer

A Well open to volcanic rock that may contain perched or semialtitude not shown but is elevated

Figure 8. Predevelopment waterlevel altitudes and contours for continuous volcanic aquifers and distribution of isolated volcanic aquifers in the Rainier Mesa and Shoshone Mountain area, Nevada Test Site, Nye County, Nevada.

Figure is designed to be printed on $11 \times 17$-inch page. To obtain full-scale image, go to http://pubs.usgs.gov/sir/2008/5044/ 
The PMTM volcanic aquifer is composed primarily of five HSUs (Bechtel Nevada, 2002; National Security Technologies, LLC, 2007). The Redrock Valley aquifer, which is one of many volcanic aquifers identified in the RMSM HFM (fig. 4), is one of the more prevalent HSUs in the northern extent of the PMTM aquifer. This welded ash-flow tuff unit is the oldest volcanic aquifer in the study area. The saturated part of the Redrock Valley aquifer reaches a maximum thickness of more than 3,000 ft near borehole WW-8 (see deep volcanic aquifer unit in section $B-B^{\prime}$ of fig. 7 ). The Belted Range aquifer, another prevalent HSU within the PMTM volcanic aquifer, overlies the Redrock Valley aquifer in the north. The Belted Range aquifer is composed of welded ash-flow tuff and lava flows. Nearly 6,000 ft of this aquifer is saturated in the northwestern part of the study area. The Belted Range aquifer forms the shallow aquifer within the PMTM volcanic aquifer near borehole WW-8 in section $B-B^{\prime}$ (fig. 7). This shallow aquifer is highly productive, having yielded about 1.5 billion gallons of water to WW-8 from 1963 to 2006. The central part of the PMTM volcanic aquifer consists of a thick (2,500 to 5,000 ft) section of the Fortymile Canyon and Timber Mountain composite units (see well "ER-30-1-1 (deep)" in appendix 3). Because these composite HSUs include, in part, permeable volcanic rock (National Security Technologies, LLC, 2007), they are mapped in this report as part of the PMTM volcanic aquifer. As portrayed in the base and alternative HFMs of National Security Technologies, LLC (2007), these composite units fill the Rainier Mesa caldera (fig. 2). This caldera is one of multiple calderas that make up the Timber Mountain caldera complex, centered about Timber Mountain, just west of the study area (fig. 1). The southernmost part of the PMTM volcanic aquifer is underlain by an HSU referred to as the Yucca Mountain/Calico Hills lava-flow aquifer. This lava-flow unit thickens westward, and in the study area, the saturated part of this aquifer reaches a thickness of more than 1,000 ft (National Security Technologies, LLC, 2007).

Pahute Mesa, Rainier Mesa, and Belted Range together form a prominent highland in the northern part of the study area (fig. 1). Here, local precipitation infiltrates downward, recharging the underlying aquifers (fig. 2). In general, water levels in the PMTM volcanic aquifer are highest beneath this local recharge area and decrease in altitude to the west and south. Water levels used to construct contours in the PMTM volcanic aquifer range in altitude from $4,197 \mathrm{ft}$ in well "ER-30-1-1 (deep)" to 4,996 ft in well "ER-19-1-2 (middle)" (fig. 8). Contours constructed from these water levels reflect this observed trend and range in altitude from 3,900 ft in the southern part of the aquifer to 5,000 ft in the Rainier Mesa area. The water-level altitudes indicated by the mapped contours in the recharge area adjacent to Rainier Mesa and in the southern part of the PMTM volcanic aquifer are uncertain because water-level data in these areas are lacking (fig. 8).
As portrayed by the mapped contours (fig. 8), much of the ground water that flows through the PMTM volcanic aquifer originates at the local highland in the north-central part of the study area. Local recharge from the highland area is evidenced by downward hydraulic gradients measured throughout the recharge area (see water levels measured in wells completed in boreholes UE-19c, WW-8, and TW-1 in appendix 3). The presence of elevated ground water in wells is common in the recharge area, especially in the immediate vicinity of Rainier Mesa (fig. 8). Confining units are prevalent in the shallow subsurface of Rainier Mesa (section $B-B^{\prime}$ of fig. 7) and likely impede the downward movement of water, thus elevating the water level. The presence of elevated water is consistent with close proximity to a local recharge area and is assumed representative of perched or semi-perched conditions (Thordarson, 1965). The rocks containing elevated water were not mapped as part of any major aquifer. Instead these rocks are considered to be local sources of recharge. Water contained within these perched and semi-perched zones moves laterally until encountering conditions that allow downward flow into an underlying aquifer.

The general flow direction within the PMTM volcanic aquifer is away from the local recharge area toward the west and south (fig. 8). In general, the horizontal hydraulic gradient decreases as the distance from the local recharge area increases (fig. 8). Small amounts of water flow into or out of the aquifer along its margins, with the direction being dependent on the local hydraulic gradient. Along the northeastern margin of the PMTM volcanic aquifer, the shallow elevated water that originates as precipitation in the local highlands and that ultimately recharges the aquifer is represented by the small inward arrows in figure 8. South of Rainier Mesa along the eastern margin of the aquifer, the interpretation is that the hydraulic gradient between the PMTM volcanic aquifer and adjacent confining units reverses. This reversal results in eastward and downward flow out of the PMTM volcanic aquifer into adjacent confining units.

A small part of another volcanic aquifer, referred to in this report as the Yucca Flat volcanic aquifer, is mapped along the east-central margin of the study area (fig. 8). Water levels are about 2,000 ft lower in altitude than levels measured in the PMTM volcanic aquifer. Ground water in the Yucca Flat volcanic aquifer has been interpreted to flow eastward toward the center of Yucca Flat (Winograd and Thordarson, 1975; Laczniak and others, 1996).

Several isolated volcanic aquifers occur between the PMTM volcanic aquifer and the eastern boundary of the study area (fig. 8). These isolated aquifers are separated from each other and from other continuous aquifers by the volcanic and siliceous confining units (ig. 7). The isolated volcanic aquifer mapped in the northern part of the study area (section $A-A^{\prime}$ in fig. 7; fig. 8) underlies an area of local recharge (fig. 2) and, therefore, is assumed to have elevated water levels; however, 
water-level data are not available to confirm this assumption. Another isolated volcanic aquifer, which includes saturated alluvium, occurs beneath Mid Valley in the southeastern part of the study area (section $A-A^{\prime}$ inn fig. 7; fig. 8). Water levels at the relatively low altitude of about $2,700 \mathrm{ft}$ are consistent with the interpretation of an isolated aquifer in an area of limited local recharge.

The isolated volcanic aquifers in the east-central part of the study area have water levels intermediate to those measured in the PMTM volcanic aquifer on the west and the Yucca Flat volcanic aquifer on the east. Water levels measured in the siliceous confining unit (wells "ER-12-2 main (upper zone)", "UE-1L (recompleted)", "UE-16d WW (2117-2293 $\mathrm{ft})$ ", "UE-16f (1479 ft)", and "UE-17a"; appendix 2) and the large difference in measured water levels between the two bounding volcanic aquifers indicate a steep horizontal hydraulic gradient across the eastern half of the study area. This steep gradient suggests limited eastward flow from the western highlands through the siliceous confining unit and isolated volcanic aquifers into Yucca Flat.

\section{Upper Carbonate Aquifer}

The upper carbonate aquifer consists of blocks of carbonate rock that are stratigraphically or structurally above and hydraulically separated from rocks that are part of the lower carbonate aquifer. Based on the degree of hydraulic connection within upper carbonate blocks and with adjacent aquifers, an upper carbonate block is mapped as a continuous or isolated aquifer. Rocks associated with the upper carbonate aquifer are present primarily in the central and eastern parts of the study area (fig. 9). Uncertainties associated with the degree of hydraulic connection in the upper carbonate aquifer in the central part of the study area are addressed with three alternative interpretations. In the southeastern part of the study area, a thrust sheet of upper carbonate rock directly overlies and is believed to have a good hydraulic connection with the lower carbonate aquifer. In this area, the upper carbonate rock is grouped with the underlying carbonate rock and mapped as part of the lower carbonate aquifer. An example of this grouping can be seen on the southern part of section $A-A^{\prime}$ by comparing the upper and lower sections (fig. 7).

The Yucca Flat upper carbonate aquifer consists of carbonate rock that is part of the upper sheet of the CP thrust (fig. 2; National Security Technologies, LLC, 2007). Carbonate-rock thickness varies across the extent of the aquifer and reaches a maximum of about 5,000 ft (Bechtel Nevada, 2006) on its eastern edge. The aquifer is underlain by low-permeability siliciclastic rock that, in this report, is considered part of the siliceous confining unit (section $B-B^{\prime}$ in fig. 7). The aquifer may be in direct hydraulic connection with the underlying lower carbonate aquifer along the eastern boundary of the study area where faulting is more intense and complex. Predevelopment water-level measurements are not available for the Yucca Flat upper carbonate aquifer. However, other available water-level measurements provide information that can be used to constrain the interpretation of contoured altitudes. All water-level altitudes shown in figure $9 A$ for the Yucca Flat upper carbonate aquifer are prefixed with a "less than" symbol, signifying that the contoured water level must be less than the posted value. On the basis of limited waterlevel data, sparse geologic information, and the presence of an underlying confining unit, water levels in the Yucca Flat upper carbonate aquifer are assumed to be slightly elevated from water levels in the underlying lower carbonate aquifer. Although this interpretation is reasonable, it is considered uncertain and is portrayed by a single dashed 2,500-ft contour in figure $9 A$. The interpretation indicates southeasterly flow toward central Yucca Flat. On the basis of this interpretation, water in the Yucca Flat upper carbonate aquifer probably exits the aquifer laterally and possibly vertically, where in contact with another aquifer east of the study area. The continuity of the Yucca Flat upper carbonate aquifer throughout its mapped extent is uncertain and will remain so without additional geologic and hydrologic data.

The Rainier Mesa upper carbonate aquifer consists of carbonate rock that is part of the upper plate of the Belted Range thrust (fig. 2; National Security Technologies, LLC, 2007). Carbonate-rock thickness in the thrust plate varies across the extent of the aquifer and reaches a maximum of about 2,500 ft (National Security Technologies, LLC, 2007). The degree to which this carbonate rock transmits water is unclear. Recent interpretations of aquifer-test data in wells "ER-12-3 main" and "ER-12-4 main" (Fryer and others, 2006; Stoller-Navarro Joint Venture, 2006) indicate hydraulic-conductivity values that are low relative to estimates of hydraulic-conductivity values in other carbonate rocks on the NTS (Belcher and others, 2001). For this analysis, the carbonate rock is assumed to be an aquifer.

The Rainier Mesa upper carbonate aquifer is penetrated by many boreholes drilled on and around the mesa (for example ER-12-1, ER-12-3, and ER-12-4 on sections $A-A^{\prime}$ and $B$ - $B$ ' in fig. 7); however, no boreholes penetrate the aquifer north or south of the mesa. Consequently, the continuity of the aquifer throughout the remainder of its mapped extent is highly uncertain. Uncertainties in flow direction and aquifer continuity related to this data deficiency are addressed by the three alternative interpretations shown in figure 9. Although Rainier Mesa is not the only area in the study with flow uncertainty, a presentation of alternatives for this area is merited because of the history of underground testing at and near Rainier Mesa. The alternative interpretations indicate significant differences in the direction of ground-water flow beneath the underground tests at and near Rainier Mesa, and thus, are presented here because each one has a different effect on any prediction of contaminant transport. 

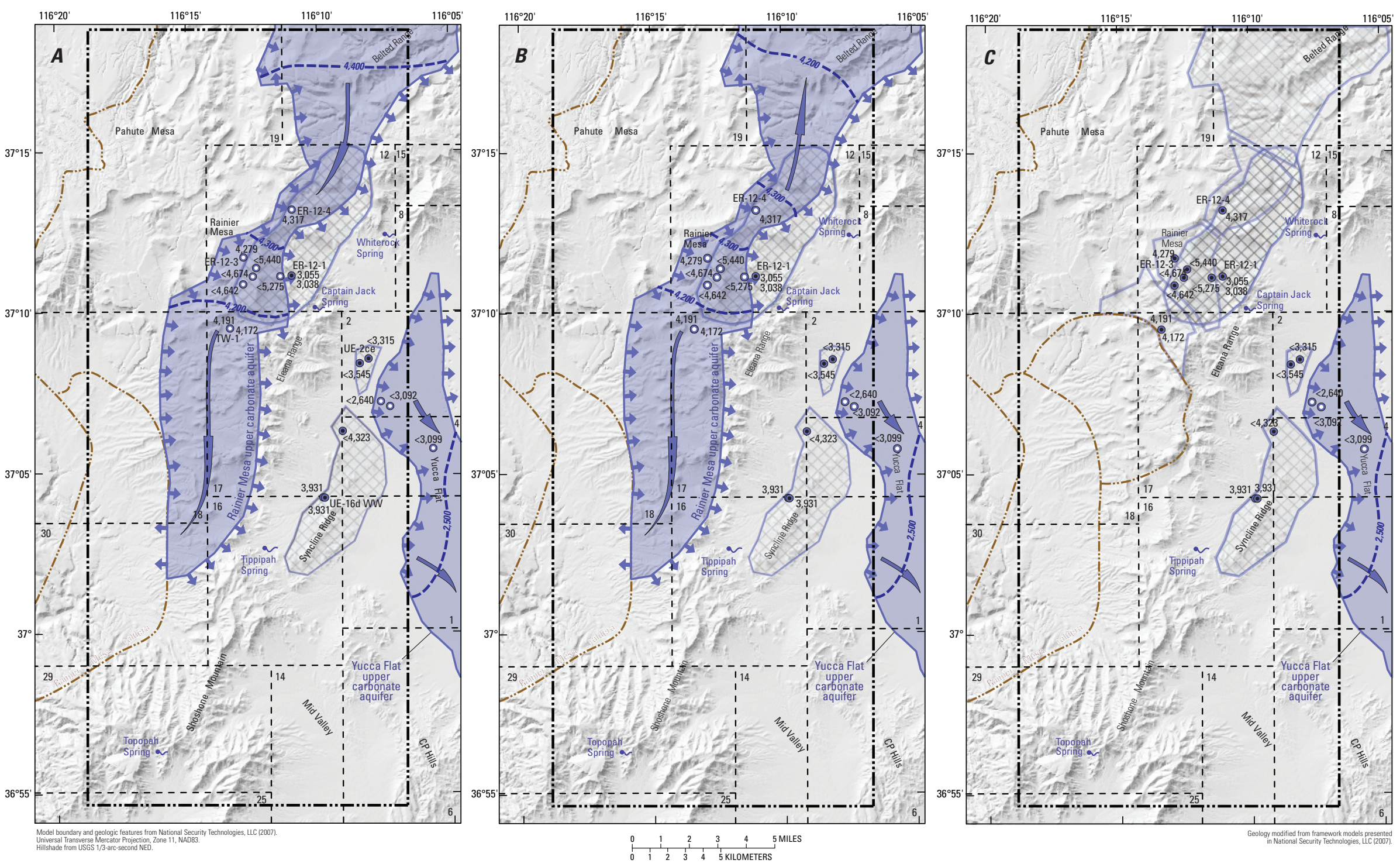

Figure 9. Alternative interpretations of predevelopment water-level altitudes and contours for continuous upper carbonate aquifers and distribution of isolated upper carbonate aquifers in the Rainier Mesa and Shoshone Mountain area, Nevada Test Site, Nye County, Nevada. (A) shows flow as southerly throughout the Rainier Mesa upper carbonate aquifer; $(B)$ shows flow as northerly in northern part of Rainier Mesa upper carbonate aquifer; and $(C)$ shows the upper carbonate aquifer in the Rainier Mesa area as a series of discontinuous, isolated blocks.

\section{Figure is designed to be printed on \\ $11 \times 17$-inch page. To obtain \\ full-scale image, go to \\ http://pubs.usgs.gov/sir/2008/5044/}


EXPLANATION

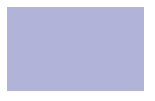

Approximate saturated extent of continuous upper carbonate aquifer

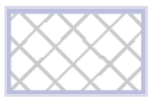

Approximate saturated extent of isolated upper carbonate aquifer - Darker hachure pattern used to help identify underlying aquifer

Framework model boundary

- $:-n-\quad$ Caldera boundary

$19 \quad$ Nevada Test Site area

_ _ _ _ - boundary - Number designates local area

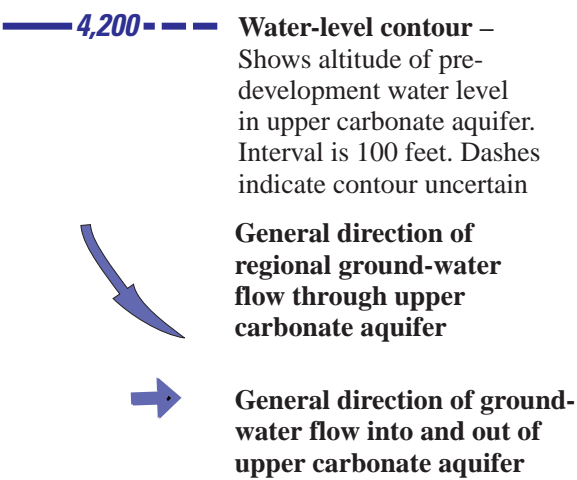

Water-level altitude and measurement

location - Shows well location and altitude used to develop contours of water-level altitude in continuous aquifer. Number is water-level altitude, in feet, at symbol location, and represents a predevelopment water level or mean of predevelopment levels measured in well: $<$ indicates altitude is a maximum. Borehole name discussed in text is labeled; names not discussed are in figure 2

\footnotetext{
4,300 Well open to upper carbonate - aquifer

4,300 Well open to isolated upper carbonate aquifer
}

Figure 9.-Continued 
Contours representing one interpretation of groundwater flow in the Rainier Mesa upper carbonate aquifer are shown in figure $9 A$. Available water-level altitudes used to develop this interpretation are posted next to the boreholes on the map and range from 4,317 ft at borehole ER-12-4 to $4,172 \mathrm{ft}$ at borehole TW-1. Water-level measurements on and near the mesa area (at boreholes ER-12-4, ER-12-3, and TW-1) show about $130 \mathrm{ft}$ of decline from north to south, indicating southerly flow from borehole ER-12-4 to ER-12-3. As portrayed in this interpretation, water from the area north of borehole ER-12-4 also is flowing south into the mesa area. This interpretation assumes that recharge in the north would sustain higher water levels, but this assumption remains unconfirmed by water-level measurements. The likely destination of southerly flowing ground water in the Rainier Mesa upper carbonate aquifer is to the PMTM volcanic aquifer in the south-central part of the study area. Flow in the Rainier Mesa upper carbonate aquifer can not discharge into the PMTM volcanic aquifer until water levels in the carbonate aquifer exceed those in the volcanic aquifer. As interpreted, the water-level gradient between these two aquifers reverses south of the boundary between NTS areas 18 and 30 (figs. 8 and $\underline{9 A}$ ). The concept of southerly flow in the upper carbonate aquifer is predicated on the existence of continuous upper carbonate rock from Rainier Mesa to the southern part of the Rainier Mesa caldera (fig. 9A), such as is postulated in several alternative HFMs of National Security Technologies, LLC (2007).

The interpretation in figure $9 A$ indicates that the dominant flow direction in the Rainier Mesa upper carbonate aquifer is southward. Water ultimately flows westward and discharges to the PMTM volcanic aquifer near the southernmost extent of the Rainier Mesa upper carbonate aquifer. As interpreted, limited flow into and out of the upper carbonate aquifer also occurs along the remainder of the western and eastern margins of the aquifer (small arrows on fig. 9A). Limited flow into the aquifer from adjacent volcanic, granitic, and siliciclastic rocks is expected along the western boundary, and limited flow out of the aquifer primarily into adjacent siliciclastic rock is

\footnotetext{
${ }^{2}$ Three carbonate zones were penetrated by borehole ER-12-1. The deepest of the three carbonate zones is interpreted in the base-case hydrostratigraphic framework model (National Security Technologies, LLC, 2007) as part of the lower carbonate aquifer, and alternatively, as an isolated sheet of thrusted carbonate rock that is part of the upper carbonate aquifer-the latter is the preferred interpretation in this report. The middle carbonate zone in ER-12-1 is interpreted in the framework model as insignificant relative to the scale of the model and is lumped in as part of a thrust sheet of the upper clastic confining unit. It is not known if this middle carbonate zone connects laterally with the upper carbonate aquifer. However, it is assumed for water-level contouring purposes, that the carbonate rock in the middle zone is disconnected from the upper carbonate aquifer and the water level is representative of the upper clastic confining unit. Based on this interpretation, water levels in the middle zone were not used for contouring the upper carbonate aquifer. The shallowest carbonate zone in ER-12-1 is unsaturated, but is connected to the Rainier Mesa upper carbonate aquifer. Only the shallow and deep upper carbonate zones in ER-12-1 are shown in cross section on figure 7.
}

expected along the eastern boundary. Vertical flow is assumed to be restricted and downward over the entire extent of the aquifer.

A second alternative interpretation portrays water-level contours in the Rainier Mesa upper carbonate aquifer as decreasing northward away from borehole ER-12-4 (fig. 9B). The basis for this interpretation is the assumption that the mesa area serves as the primary recharge area for the Rainier Mesa upper carbonate aquifer. In this alternative, the local influx of recharge creates a ground-water mound centered on the mesa area, although water-level measurements are not available north of borehole ER-12-4 to confirm its existence. However, this alternative interpretation is supported by the combination of carbonate rock at and near land surface near borehole ER-12-1 (Slate and others, 2000; appendix 3), high precipitation (Soulé, 2006), and likely infiltration (Hevesi and others, 2003). The presence of shallow carbonate rock in combination with relatively high annual precipitation could allow sufficient recharge through the near-surface, fractured, carbonate rock to create a local mound. The primary difference between this and the first interpretation is that some of the ground water in the Rainier Mesa upper carbonate aquifer would flow northward away from the mesa area rather than southward into the mesa area.

A third alternative interpretation portrays all the carbonate rock beneath Rainier Mesa as multiple disconnected blocks that form aquifers isolated not only from the regional flow system but from each other (fig. 9C). This interpretation is predicated on the notion that the significant and complex faulting in the area juxtaposes fractured carbonate rock against less permeable rock. The outcome of this is manifested in a rather complicated hydrostratigraphic framework and is evidenced at borehole ER-12-1, where the borehole penetrates three separate carbonate-rock zones interlayered with younger siliciclastic rocks. The complex stratigraphy encountered at borehole ER-12-1 is interpreted to have resulted from imbricate thrust faulting (National Security Technologies, LLC, 2007). The complexity of the local geology indicates that the three-dimensional configuration of the upper carbonate aquifer may be much more discontinuous than represented in the HFMs ${ }^{2}$. Large differences in nearby water levels and the highly undulating surface of the local carbonate rock also support an interpretation whereby the carbonate rock beneath the mesa area forms hydraulically isolated carbonate blocks rather than a single continuous aquifer throughout the area. For example, the carbonate water level in well "TW-1 (3700-4206 ft)", just south of Rainier Mesa, is about $100 \mathrm{ft}$ lower than water levels measured in wells open to carbonate rock beneath the mesa. Additionally, the surface of the carbonate rock at borehole TW- 1 is about 2,500 ft lower than encountered at boreholes drilled on Rainier Mesa. This relatively large decline in water level, in combination with a large change in the altitude of the carbonate-rock surface, could be interpreted to support a hydraulic disconnect between the carbonate rocks encountered at the two boreholes. 
The third alternative differs from the first two alternatives in that any regional lateral ground-water flow in the upper carbonate rock beneath Rainier Mesa would be restricted. Measured water levels in the carbonate rock and in the adjacent confining unit (appendix 2) indicate a steep vertical hydraulic gradient and limited vertical flow. Based on this observation, differences in water levels measured in the carbonate rock may not be associated with lateral flow but simply may reflect the steep downward gradient within the confining unit. For example, water levels measured in carbonate rock at wells "ER-12-3 main" and "ER-12-4 main" are similar in altitude to water levels measured in confining units at wells "WW-8 (5290-5490 ft)" and "ER-19-1-1 (deep)" (table 1). Water levels measured in these different units may be similar to each other, not because they are laterally connected, but because they coincidentally represent similar hydraulic heads in the steep downward vertical gradient within a regionally extensive confining unit. The isolation of the carbonate blocks predicated by this third interpretation restricts lateral and vertical flow in the saturated system beneath Rainier Mesa. This inability of the saturated system to transmit water necessitates that either (1) recharge on Rainier Mesa is less than historically estimated (for example, Blankennagel and Weir, 1973; Hevesi and others, 2003), or (2) recharge moves laterally within perched and semi-perched systems into adjacent volcanic aquifers.

Several other carbonate aquifers are mapped in each of the interpretations in figure 9 as being isolated from the each other and from the regional flow system (figs. 7 and 9). One of these isolated aquifers is encountered at the bottom of borehole ER-12-1 and is interpreted as a relatively small block of thrusted carbonate rock that lies beneath the shallower Rainier Mesa upper carbonate aquifer (fig. 9) and above the much deeper, lower carbonate aquifer (figs. 7 and 10). Although the lateral extent of this isolated carbonate block is highly conjectural, its isolation from the mapped Rainier Mesa upper carbonate aquifer and the underlying lower carbonate rock is supported strongly by water-level measurements. The water level measured in this carbonate block is at an altitude of 3,055 ft, which is about 1,200 ft lower than levels in the shallow Rainier Mesa upper carbonate aquifer and $600 \mathrm{ft}$ higher than levels measured to the south and east in the deeper lower carbonate aquifer. Differences of this magnitude indicate that the carbonate block with this intermediate water level is hydraulically disconnected from both the Rainier Mesa upper carbonate aquifer and the lower carbonate aquifer.

Another block of carbonate rock mapped as isolated upper carbonate aquifer is in the Syncline Ridge area of the NTS (fig. 9). This aquifer is mapped as isolated because measured water levels are elevated relative to other nearby carbonate water levels to the east, and the carbonate aquifer is underlain entirely by confining unit (see borehole UE-16d WW on section $A-A^{\prime}$ in fig. 7). The aquifer is composed of limestone of Mississippian age that is near or exposed at the surface throughout the area (Slate and others, 2000). Surface and near-surface exposure likely allows some recharge of direct precipitation and of runoff from the surrounding highlands (fig. 2). One well in the area, "UE-16d WW", produced $760 \mathrm{Mgal}$ of water from this fairly extensive but isolated aquifer between 1981 and 2006 (U.S. Geological Survey, 2008), indicating that the aquifer can be productive locally. Although data are sparse, the few available measurements indicate that the water level in the aquifer is intermediate between higher levels in volcanic and upper carbonate aquifers to the west and lower levels in volcanic and upper carbonate aquifers to the east (fig. 9). A possible hydraulic connection may allow some water to flow from this isolated carbonate aquifer to the isolated volcanic aquifer immediately to the east (fig. 8).

A small carbonate block in the west-central part of NTS area 2 also is mapped as an isolated upper carbonate aquifer (fig. 9). The HFM (National Security Technologies, LLC, 2007) portrays this aquifer as being geologically connected to the large block of carbonate rock to the east, which is mapped in this report as the Yucca Flat upper carbonate aquifer. However, water levels measured in well "UE-2ce" and measurements in other nearby wells open to carbonate rock suggest that the carbonate aquifer at well "UE-2ce" is hydraulically isolated from the Yucca Flat upper carbonate aquifer. The saturated part of this isolated carbonate aquifer is nearly surrounded by low-permeability rock and structures that could impede ground-water flow and account for the elevated water levels. Minor modifications in the HFM to the structural top of the carbonate unit, which changes rapidly across the local area, would allow complete isolation of this carbonate aquifer. Well "UE-2ce" was pumped between 1977 and 1984, producing about $11 \mathrm{Mgal}$ of water from the aquifer. However, the aquifer sustained a pumping rate of less than $10 \mathrm{gal} / \mathrm{min}$ and the recovery of the water level took about 10 years (Fenelon, 2005). The low production and recovery rates associated with the carbonate rock open to the well support designating this upper carbonate aquifer as either isolated or of low permeability.

\section{Lower Carbonate Aquifer}

The lower carbonate aquifer consists of generally continuous, hydraulically connected, Cambrian- to Devonianage, dolomite and limestone. The aquifer is present throughout most of the study area except beneath the major caldera complexes in the northwest and the Gold Meadows and Climax stock areas in the north-central and northeastern parts of the study area, respectively (fig. 10). Throughout its extent, the aquifer, as modeled (National Security Technologies, LLC, 2007), maintains a fairly uniform thickness that ranges from about 10,000 to 13,000 ft (fig. 7) and, in most areas, lies from 


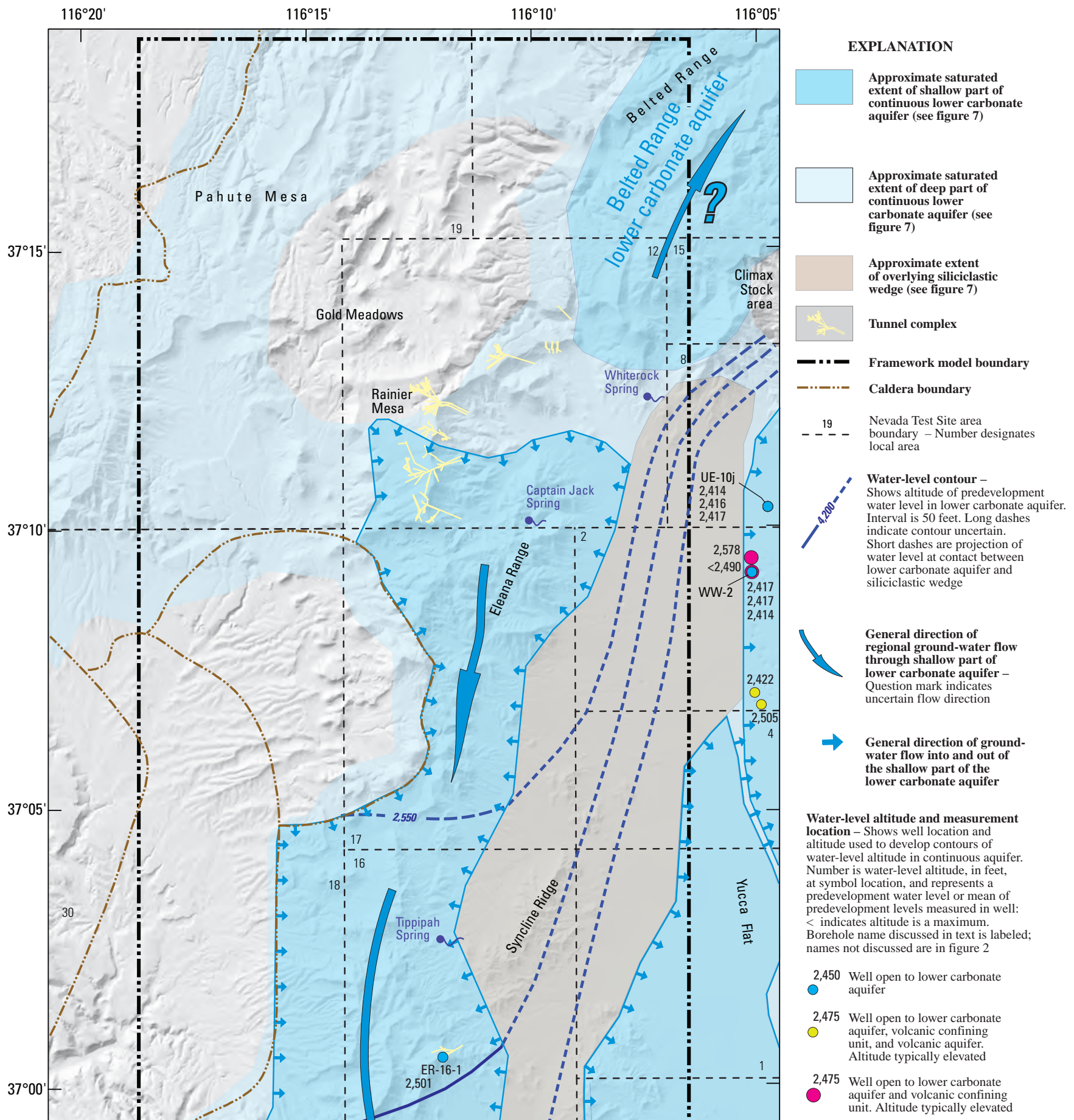

Figure 10. Predevelopment waterlevel altitudes and contours for continuous lower carbonate aquifers in the Rainier Mesa and Shoshone Mountain area, Nevada Test Site, Nye County, Nevada.

Figure is designed to be printed on $11 \times 17$-inch page. To obtain full-scale image, go to http://pubs.usgs.gov/sir/2008/5044/ 
1,000 to $10,000 \mathrm{ft}$ below land surface. The aquifer is overlain almost entirely by siliceous confining unit and typically is fully saturated. In some areas, the top part of the lower carbonate aquifer is unsaturated, as exemplified at borehole ER-16-1 (section $A$ - $A^{\prime}$ of fig. 7 and appendix 3 ). The top part of the aquifer is believed to be unsaturated in the southeastern corner of the study area beneath CP Hills and in small areas that follow the spine of a northeast-trending anticline in the carbonate rock that roughly coincides with the large flow arrows shown in figure 10 west of the siliciclastic wedge. The lower carbonate rock has been delineated into two continuous aquifers in the study area-an extensive aquifer referred to as the Yucca Flat-Shoshone Mountain (YFSM) lower carbonate aquifer and a much smaller aquifer in the northeastern part of the study area referred to as the Belted Range lower carbonate aquifer (fig. 10).

Water-level data in the lower carbonate aquifer are sparse. Well drilling into the lower carbonate aquifer in the study area is restricted by the excessive depths required to reach the surface of the aquifer. Only three boreholes, ER-16-1, WW-2, and UE-10j, have water-level measurements taken from an interval or intervals open to the lower carbonate aquifer. Water levels in these intervals range in altitude from 2,414 ft at WW-2 and UE-10j to 2,501 ft at ER-16-1 (fig. 10). Contours shown in figure 10 portray the interpreted water-level distribution in the lower carbonate aquifer. This interpretation is consistent with water levels from several wells open to the lower carbonate aquifer east and southwest of the study area. Given the paucity of water-level data, more than one interpretation of the water-level distribution is possible.

The interpretation shown in figure 10 is focused primarily on the upper part of the lower carbonate aquifer. The upper part of the aquifer is referred to as "shallow" in this report and is that part of the aquifer that likely has the most influence on the transport of the test-generated contaminants. The shallow part of the lower carbonate aquifer is defined arbitrarily as the area where the aquifer is less than 7,500 ft below land surface and is mapped as the darker blue lower carbonate unit in figures 7 and $\underline{10}$.

The YFSM lower carbonate aquifer is overlain in the central part of the study area by a north-south trending wedge of thick siliciclastic rock (fig. 10). The rock making up the siliciclastic wedge includes low-permeability rock that is part of the siliceous confining unit (fig. 7). As interpreted, the wedge restricts the eastward flow of ground water in the shallow western part of the YFSM lower carbonate aquifer, resulting in a southerly flow direction (fig. 10). In the deep part of the YFSM lower carbonate aquifer (not contoured), where the influences of the siliciclastic wedge are negligible, an eastward flow direction is suspected. As the siliciclastic wedge thins approaching the southern boundary of the study area, the contours indicate that some of the water moving southward on the west side of the siliciclastic wedge moves in an east-southeast direction. Ground-water flow east of the siliciclastic wedge in the YFSM lower carbonate aquifer is predominantly east-southeast. Alternatively, if the siliciclastic wedge is not a major impediment to ground-water flow, then the entire shallow part of the YFSM lower carbonate aquifer within the study area likely would have a strong easterly flow component.

The direction of flow and the continuity of the carbonate rock in the Belted Range lower carbonate aquifer are uncertain (fig. 10). As interpreted, the Belted Range lower carbonate aquifer is hydraulically disconnected from the shallow part of the YFSM lower carbonate aquifer. The disconnect occurs just northeast of Rainier Mesa and may result from (1) a thick sequence of low-permeability rock in the area, which overlies carbonate rock where it is excessively deep, or (2) the presence of a geologic structure. Flow in the Belted Range lower carbonate aquifer is interpreted to flow northward; however, water-level data do not exist to support this interpretation. No wells are open to the aquifer throughout its mapped extent. Water levels in pre-Tertiary rock immediately east of the study area (east of the Belted Range lower carbonate aquifer that is mapped in figure 10) are highly elevated with respect to levels measured throughout the YFSM lower carbonate aquifer (Winograd and Thordarson, 1975, fig. 32). The elevated water levels in these rocks support the interpretation of a hydraulic disconnect between the Belted Range and YFSM lower carbonate aquifers in the study area.

The lower carbonate aquifer is the regional drain for water in the study area. In most places, water levels in overlying aquifers are 1,000 to 2,000 ft higher than in the lower carbonate aquifer. The steep gradient and large difference is maintained throughout the study area by a thick (generally greater than 1,000 ft) intervening siliceous confining unit (fig. 7). Although the vertical hydraulic gradient forces some water downward and outward through the confining unit and into the lower carbonate aquifer, the inflow into the lower carbonate aquifer is assumed small because it is restricted by the low permeability of the intervening confining unit.

A higher potential for recharge into the lower carbonate aquifer is possible in four relatively small areas where the top of the lower carbonate aquifer is at or near land surface (less than 1,000 ft) and near an area of potential recharge (fig. 2). These four areas are (1) on the eastern boundary of the study area north of NTS area 15; (2) just north of borehole UE-10j; (3) east of the southernmost extent of the siliciclastic wedge; and (4) in the highlands just west of Mid Valley (fig. 10). Potential evidence of local recharge into the lower carbonate aquifer is seen in hydrographs from wells "UE-10j (2232-2297 ft)" and "WW-2 (3422 ft)". Both hydrographs show a marked rise in water level beginning in September 2005 (appendix 1). This water-level rise may be a pressure response related to recharge resulting from the much wetter-than-normal conditions on Rainier Mesa and other highland areas in the winter of 2004. From October 2004 to March 2005, about 20 in. of precipitation were measured on Rainier Mesa, whereas the long-term average precipitation for this period is less than 8 in. (Air Resources Laboratory, Special Operations and Research Division, 2007). 


\section{Regional-Flow Depiction and Implications}

The transport of test-generated contaminants is not necessarily constrained to a single aquifer. To address the potential for contaminants to move across aquifer boundaries, the mapped continuous aquifers were viewed together in the context of an interconnected regional flow system. Potential geologic and hydraulic connections between aquifers were evaluated to identify the flow paths most likely to control transport away from areas of past underground testing at Rainier Mesa and Shoshone Mountain. Inherent in this evaluation are uncertainties that can confound any interpretation of regional flow. These uncertainties have implications for contaminant transport and generally result from a lack of data. The more relevant implications of these uncertainties are discussed in this section, as are some suggestions for additional data collection directed at reducing these uncertainties.

Continuous aquifers of each aquifer type were combined onto a single map to evaluate the interconnection between these aquifers and the potential for regional ground-water flow (fig. 11). Regional flow is described through a series of tributary flow systems. Tributary flow systems consist of a part of a continuous aquifer, an entire continuous aquifer, or a combination of parts of continuous aquifers (fig. 3) that when taken together form a regional flow path. One or more tributary flow systems make up a regional flow system (fig. 3). Four tributary flow systems were identified and mapped in the study area: the Pahute Mesa, Fortymile Wash, Shoshone Mountain, and Yucca Flat tributary flow systems (fig. 11). A potential fifth tributary flow system consists of the carbonate rock that forms the lower carbonate aquifer in the northeastern part of the study area. This system was not named because its flow paths and interconnection with other aquifers within and outside the study area are highly speculative.

The Pahute Mesa tributary flow system (fig. 11) consists of the northern part of the PMTM volcanic aquifer (fig. 8). Water in this system generally originates from recharge in the highland areas on and around Rainier and Pahute Mesas. Ground-water flow is dominantly southwest toward regional springs and seeps in discharge areas located outside the study area to the west and southwest (Laczniak and others, 1996). Timber Mountain (fig. 1) may coincide with a divide between southwesterly flow in the Pahute Mesa tributary flow system and southerly flow in the Fortymile Wash tributary flow system. The presence of a divide and whether this divide is caused by a ground-water mound from recharge on the mountain, by the low permeability of intra-caldera rock, or by geologic structures associated with the formation and presence of the caldera remain uncertain.

The Fortymile Wash tributary flow system (fig. 11) may consist of the Rainier Mesa upper carbonate aquifer (figs. $9 A$ and $\underline{9 B}$ ) and the southern part of the PMTM volcanic aquifer (fig. 8). If water in the northern part of the Rainier Mesa upper carbonate aquifer is assumed to flow south (the first water-level alternative, fig. 9A), then some water in the Fortymile Wash tributary flow system originates north of the study area. Significant amounts of water also enter the flow system as recharge in the Rainier Mesa area. The first two alternatives (figs. $9 A$ and $9 B$ ) extend the Rainier Mesa upper carbonate aquifer into the southern half of the study area. In these alternatives, the Rainier Mesa upper carbonate aquifer is separated hydraulically from the overlying PMTM volcanic aquifer in the central part of the study area. Only at the southern end of the mapped extent of the upper carbonate aquifer can water discharge into the volcanic aquifer; at this junction, flows from the two aquifers would merge. If the Rainier Mesa upper carbonate aquifer consists of disconnected blocks of carbonate rock (the third water-level alternative, fig. 9C), then the Fortymile Wash tributary flow system in the study area consists solely of the PMTM volcanic aquifer. In this alternative, water originates in the highlands near Rainier Mesa and flows primarily in a southerly direction through the PMTM volcanic aquifer, as shown on figure 11 by the two westernmost arrows south of Rainier Mesa. For all three upper carbonate water-level alternatives, flow in the Fortymile Wash tributary flow system continues in a south-southwest direction under Fortymile Wash toward the Amargosa Desert (fig. 1). Ultimately, water along this flow path discharges to regional springs and seeps in discharge areas located south and southwest of the study area (Laczniak and others, 1996).

The Shoshone Mountain tributary flow system (fig. 11) extends beneath the Eleana Range and Shoshone Mountain and consists of carbonate rock that forms the western lobe of the YFSM lower carbonate aquifer (fig. 10). Recharge to this aquifer is restricted by the low permeability of the overlying siliceous confining unit. Ground water in the shallow part of this tributary system flows south, ultimately discharging at regional springs and seeps in discharge areas south or southwest of the study area (Laczniak and others, 1996).

The Yucca Flat tributary flow system extends throughout the eastern part of the study area (fig. 11) and includes volcanic rock that forms the Yucca Flat volcanic aquifer (fig. 8), carbonate rock that forms the Yucca Flat upper carbonate aquifer (fig. 9), and carbonate rock that forms the eastern lobe of the YFSM lower carbonate aquifer (fig. 10). 


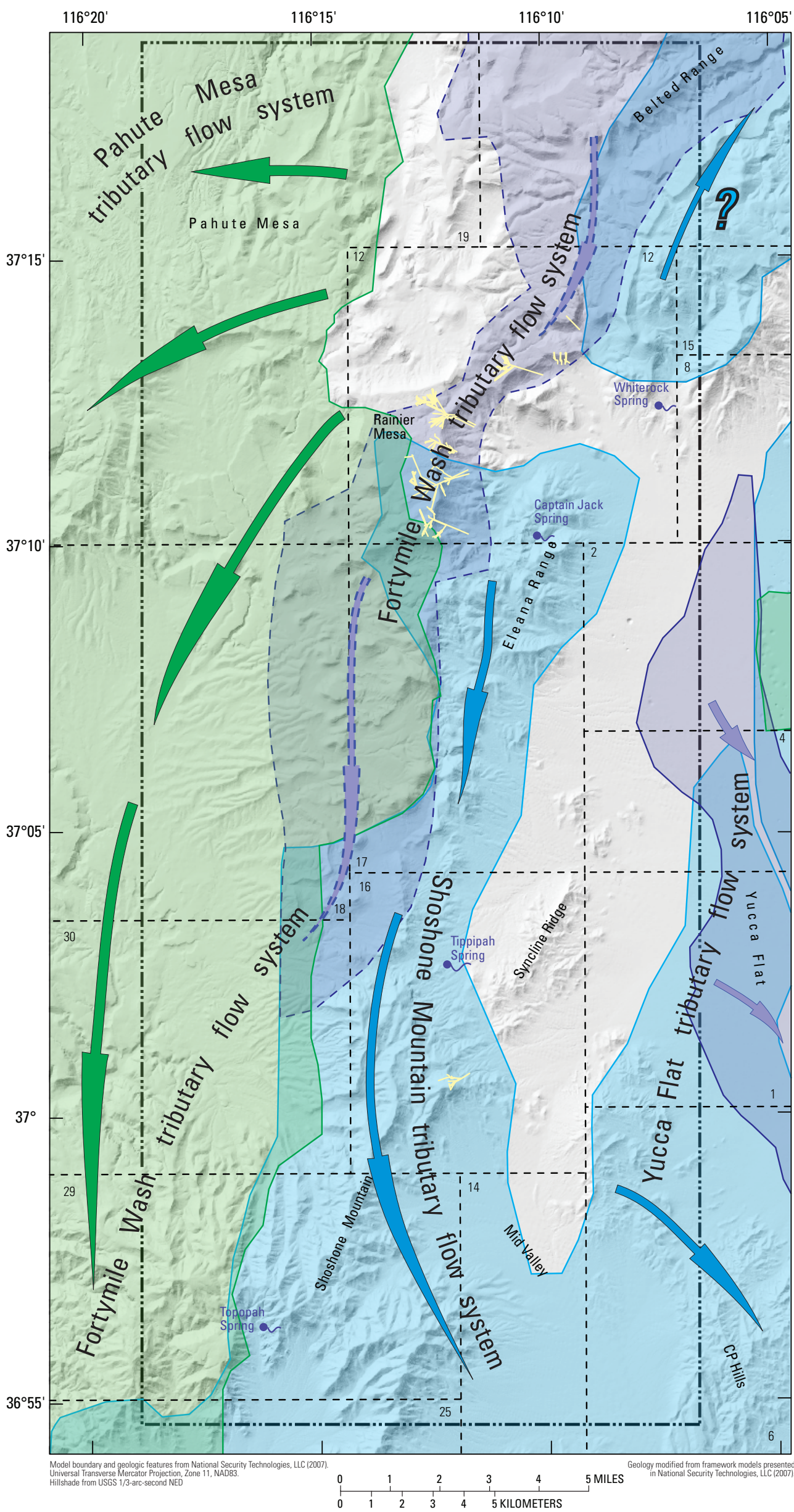

EXPLANATION

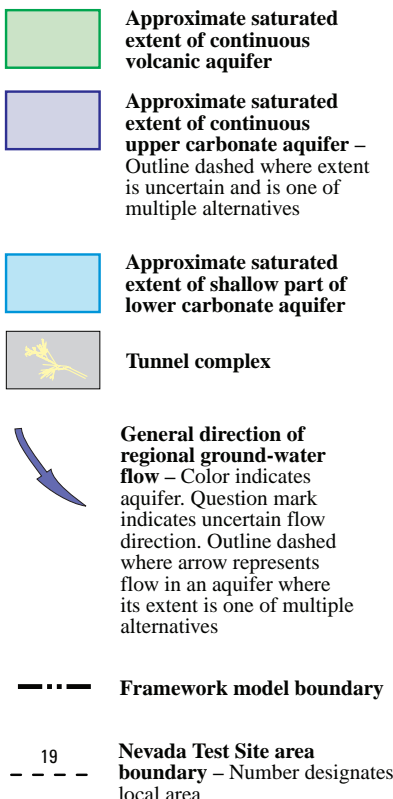

Figure 11. Tributary ground-water flow systems and general directions of ground-water flow in the Rainier Mesa and Shoshone Mountain area, Nevada Test Site, Nye County, Nevada.

Figure is designed to be printed on
$11 \times 17-$ inch page. To obtain
full-scale image, go to
http://pubs.usgs.gov/sir/2008/5044/


Water in the Yucca Flat volcanic aquifer drains slowly eastward and downward into the YFSM lower carbonate aquifer east of the study area, near the center of Yucca Flat (Winograd and Thordarson, 1975). Water in the Yucca Flat upper carbonate aquifer flows east-southeast and enters the lower carbonate aquifer along the eastern edge of the study area, or possibly even further east, where the two carbonate aquifers may be in good hydraulic connection. Ground water in the Yucca Flat tributary flow system moves southeast through the YFSM lower carbonate aquifer and ultimately discharges at regional springs and seeps in discharge areas south of the study area (Laczniak and others, 1996).

Ground-water flow beneath Rainier Mesa is uncertain. The flow scenario portrayed in figure 11 would move any test-generated contaminants that were transported into the saturated rock directly beneath the Rainier Mesa testing area southward away from the mesa area. These contaminants would move south by way of the Fortymile Wash tributary flow system, first through the Rainier Mesa upper carbonate aquifer, as portrayed in figure 9A, and then through the PMTM volcanic aquifer.

Two additional alternative interpretations for transport of test-generated contaminants from the Rainier Mesa area can be derived by substituting alternative water-level contour configurations for the upper carbonate aquifer (figs. $9 \mathrm{~B}$ and $\underline{9 C}$ ). Assuming the alternative configuration presented in figure $9 B$, the transport of contaminants entering the Rainier Mesa upper carbonate aquifer from the northernmost tunnels in the Rainier Mesa area is northward. Assuming the alternative configuration presented in figure $9 C$, the transport of contaminants entering the upper carbonate aquifer is restricted to the locally isolated disconnected blocks of carbonate rock that underlie the tunnel complexes. Any transport beyond one of these locally isolated blocks is impeded and controlled by the low permeability of the siliceous confining unit.

A final alternative for transport of test-generated contaminants from the Rainier Mesa area assumes that transport of contaminants in the perched or semi-perched system is primarily lateral rather than vertical. In this alternative, contaminants in perched and semi-perched zones would migrate west to the PMTM volcanic aquifer rather than downward into the Rainier Mesa upper carbonate aquifer. Once in the volcanic aquifer, contaminants would move westward by way of the Pahute Mesa tributary flow system or southwestward by way of the Fortymile Wash tributary flow system.

The rapid transport of contaminants from the Rainier Mesa area into the lower carbonate rocks of the Shoshone Mountain tributary flow system is unlikely because no direct hydraulic connection is believed to exist. The only pathway for contaminant transport from Rainer Mesa into the Shoshone Mountain flow system is by downward leakage through 3,000 to $4,000 \mathrm{ft}$ of the siliceous confining unit. Downward movement through this low-permeability confining unit is slow, and accordingly, travel times would be long (probably exceeding 1,000 years).

Contaminants introduced into the subsurface by testing in the tunnel complex beneath Shoshone Mountain must move downward through about 2,500 ft of mostly unsaturated, low-permeability volcanic and siliceous confining units and some unsaturated carbonate rock before reaching the groundwater flow system. In the unlikely event of this long-distance migration, contaminants would enter saturated carbonate rock that forms the upper part of the western lobe of the YFSM lower carbonate aquifer (figs. 7 and 10). Once in this aquifer, contaminants would move southward out of the study area through the Shoshone Mountain tributary flow system (fig. 11). Although flow paths in the YFSM lower carbonate aquifer appear, at first glance, to be reasonably certain, waterlevel contours and flow directions in the study area essentially hinge on a single data point at borehole ER-16-1.

Geologic and water-level data from several strategically placed drill holes could reduce flow-path uncertainties. A deep hole on the east side of the Redrock Valley caldera (fig. 2), an uncertain modeled caldera structure (National Security Technologies, LLC, 2007), could serve multiple purposes. First, the drill hole could prove or disprove the existence of the caldera. If the caldera is present, then the likelihood of the Rainier Mesa upper carbonate aquifer extending to the south and connecting to the PMTM volcanic aquifer diminishes considerably. The presence of the caldera increases the likelihood of a locally isolated upper carbonate aquifer beneath the mesa area (fig. 9C). If the caldera is absent, then the proposed hole could be drilled into underlying carbonate rock to determine the existence and thickness of the Rainier Mesa upper carbonate aquifer and the YFSM lower carbonate aquifer. A hole completed in the aquifers present at this location would provide important water-level information regarding flow in the area. The geologic and hydrologic information obtained from the completed well or wells would help determine the existence, extent and hydraulic connection of the upper carbonate aquifer between Rainier Mesa and areas to the south, determine the depth of the lower carbonate aquifer at the well location, and support or refute the favored interpretation of southerly flow through the Shoshone Mountain tributary flow system in the area north of borehole ER-16-1. A water level at this location also would help resolve uncertainties in the HFM as to the continuity of the lower carbonate aquifer with carbonate rock penetrated at the bottom of borehole ER-12-1.

A deep drill hole in the northeastern part of the study area, northeast of borehole ER-12-4, would reduce the uncertainty in the direction of flow in the northern part of the Rainier Mesa upper carbonate aquifer. This hole would provide information in an area where no data currently exist. The same drill hole, if strategically located, could be drilled deep enough to penetrate both the Rainier Mesa upper 
carbonate aquifer and the Belted Range lower carbonate aquifer. Water levels and geologic data from a hole having a multi-level completion would provide invaluable information. A water level in the upper carbonate aquifer would prove or disprove the presence of a water-level mound under the mesa area and whether flow in the upper carbonate aquifer in the northern part of the study area is to the north or south. A water level in the lower carbonate aquifer near this location would provide an estimate of the water-level altitude and flow direction, which currently are unknown. Water levels also could help evaluate potential interactions between the upper and lower carbonate aquifers in this part of the study area.

Drill holes sited south and southwest of borehole ER-16-1 would reduce uncertainties about the continuity of the PMTM volcanic aquifer and about the direction of ground-water flow in the Shoshone Mountain tributary flow system. Currently, rock that is part of the volcanic composite unit SHUT is assumed part of the PMTM volcanic aquifer. Geologic data from a well located in this area would provide information as to the water-transmitting properties of the volcanic rock present throughout this area. A well in the Shoshone Mountain tributary flow system at the far southern end of the study area would help confirm whether the predominant direction of flow in this system is southerly.

\section{Summary}

Accurate prediction of transport of radionuclides and other test-generated contaminants beneath the Rainier Mesa and Shoshone Mountain (RMSM) area requires an understanding of the rate and direction of ground-water flow within the major aquifers of the study area. The spatial distribution of the water-level altitudes across this area, a major control on the direction and rate of transport, has been portrayed historically by maps showing a single set of generalized water-level contours. These maps, by their very nature, ignore vertical flow components and depict the complex subsurface geology as a single, continuous, regionally extensive flow system. Contrarily, the ground-water flow system is made up of multiple aquifers that are separated hydraulically by confining units. The hydraulic separation creates multiple, semi-independent flow systems where flow is controlled by the head gradient within each aquifer.

The approach used to characterize ground-water flow was to construct water-level contour maps of the major aquifers forming distinct flow systems in the study area. Aquifers were identified and mapped by using a composite hydrostratigraphic framework model derived by merging previously published three-dimensional hydrostratigraphic framework models for the RMSM, Yucca Flat, and Pahute Mesa areas. Framework units with similar hydraulic properties and rock type were grouped together into seven subsurface hydrologic unit types
(SHUTs): the alluvial aquifer, volcanic aquifer, volcanic confining unit, volcanic composite unit, upper carbonate aquifer, lower carbonate aquifer, and siliceous confining unit. Permeable SHUTs were grouped into three aquifer types (volcanic, upper carbonate, and lower carbonate) and mapped as either continuous or isolated aquifers.

Mean, predevelopment, water-level altitudes were calculated for 133 wells in the study area. Water levels associated with one of the three aquifer types were plotted and contoured to represent predevelopment conditions in each of the major aquifers. Contouring took into consideration water-level gradients, likely recharge areas, discharge areas, and lateral and vertical continuity of flow systems. Maps included in the report show the spatial distribution, dominant flow directions, and areas of lateral inflows to and outflows from each of the aquifers. Contoured surfaces were used to delineate regional and tributary (subregional) flow systems.

Hydraulically well-connected volcanic rocks form a continuous volcanic aquifer that spans the entire western half of the study area. This aquifer constitutes one of the major aquifers in the study area and is referred to as the Pahute Mesa-Timber Mountain (PMTM) volcanic aquifer. Much of the ground water that flows through this aquifer originates as recharge in the local highland in the north-central part of the study area and flows toward the west and south. The presence of elevated ground water in volcanic rocks is common on Rainier Mesa. Rocks containing elevated water are not mapped as part of the PMTM volcanic aquifer, but instead are considered as a source of local recharge. In the eastern half of the study area, saturated volcanic rocks are less continuous and less connected hydraulically. These disconnected volcanic rocks form a few scattered volcanic aquifers that typically occur beneath the larger topographic valleys.

The upper carbonate aquifer consists of continuous, hydraulically connected, carbonate rocks that are stratigraphically or structurally above and hydraulically separated from carbonate rock that makes up the lower carbonate aquifer. The upper carbonate aquifer is present primarily in the north-central part of the study area (Rainier Mesa upper carbonate aquifer) and along the eastern boundary of the study area (Yucca Flat upper carbonate aquifer). Several other disconnected carbonate blocks in the study area are mapped as aquifers that are isolated from each other and from the regional flow system. The mapped extent and continuity of the Rainier Mesa upper carbonate aquifer south of Rainier Mesa are highly uncertain. Uncertainties in flow direction and aquifer continuity are portrayed by alternative interpretations. In two interpretations, water from the Rainier Mesa upper carbonate aquifer flows south and likely discharges to the PMTM volcanic aquifer in the south-central part of the study area. In a third interpretation, the upper carbonate rock beneath Rainier Mesa is portrayed as disconnected blocks that form isolated aquifers. 
The lower carbonate aquifer persists throughout most of the study area except beneath major caldera complexes and granitic stocks. In most places, water levels in overlying aquifers are 1,000 to 2,000 feet higher than in the lower carbonate aquifer. The steep gradient and large difference is maintained by a thick intervening siliceous confining unit that allows only small amounts of inflow into the lower carbonate aquifer. The primary section of lower carbonate aquifer is the extensive Yucca Flat-Shoshone Mountain (YFSM) lower carbonate aquifer. This aquifer is overlain by a north-south trending wedge of thick siliciclastic rock in the central part of the study area. The wedge is interpreted to restrict eastward flow in the shallow part of the carbonate aquifer, forming a western and an eastern lobe of carbonate aquifer.

A series of tributary flow systems are used to describe regional flow in the study area. Tributary flow systems consist of a part of a continuous aquifer, an entire continuous aquifer, or a combination of parts of continuous aquifers. One or more tributary flow systems make up a regional flow system. Four tributary flow systems were identified and mapped in the study area: Pahute Mesa, Fortymile Wash, Shoshone Mountain, and Yucca Flat tributary flow systems. The Pahute Mesa tributary flow system consists of the northern part of the PMTM volcanic aquifer. Water in this system originates from recharge in the highland areas on and around Rainier and Pahute Mesas and flows southwest. The Fortymile Wash tributary flow system consists of the southern part of the PMTM volcanic aquifer and, potentially, the Rainier Mesa upper carbonate aquifer. One water-level interpretation allows for water at the southern end of this upper carbonate aquifer to discharge into the volcanic aquifer, where it continues in a south-southwest direction under Fortymile Wash. The Shoshone Mountain tributary flow system consists of carbonate rock that forms the western lobe of the YFSM lower carbonate aquifer. Ground water in the shallow part of this system flows southward out of the study area. The Yucca Flat tributary flow system extends throughout the eastern part of the study area and includes volcanic aquifer and upper and lower carbonate aquifers. Ground water in this system flows southeast out of the study area, primarily through the YFSM lower carbonate aquifer.

Ground-water flow beneath Rainier Mesa is uncertain and several alternative scenarios are proposed to illustrate the potential for movement of test-generated contaminants that are transported into the saturated rock directly beneath the Rainier Mesa testing area. One alternative is southward movement away from the mesa area by way of the Fortymile Wash tributary flow system. Other alternatives include (1) northern transport of contaminants from the northernmost tunnels in the Rainier Mesa area, (2) minimal movement of contaminants because of containment within disconnected blocks of upper carbonate rock that underlie the tunnel complexes, and (3) westward movement through the volcanic aquifer. Contaminants introduced into the subsurface by testing in the tunnel complex beneath Shoshone Mountain must move downward through about 2,500 feet of mostly unsaturated, low-permeability rock before reaching the ground-water flow system. Any contaminants that enter the saturated carbonate rock will move southward out of the study area through the Shoshone Mountain tributary flow system.

Several strategically placed drill holes are proposed that could provide data to prove or disprove alternative HFM models, and consequently, reduce uncertainties in groundwater flow and contaminant transport. One area of uncertainty is in the vicinity of the proposed Redrock Valley caldera, and a second area is in the northeastern part of the study area in the northern part of the Rainier Mesa upper carbonate aquifer.

\section{References Cited}

Air Resources Laboratory, Special Operations and Research Division, 2007, Nevada Test Site (NTS) climatological rain gauge network: National Oceanic and Atmospheric Administration, accessed August 2007 at http://www.sord. nv.doe.gov/home climate rain.htm

Bechtel Nevada, 2002, A hydrostratigraphic model and alternatives for the groundwater flow and contaminant transport model of Corrective Action Units 101 and 102-Central and western Pahute Mesa, Nye County, Nevada: U.S. Department of Energy Report DOE/ NV/11718-706, 383 p.

Bechtel Nevada, 2006, A hydrostratigraphic model and alternatives for the groundwater flow and contaminant transport model of Corrective Action Unit 97-Yucca Flat-Climax Mine, Lincoln and Nye Counties, Nevada: U.S. Department of Energy Report DOE/NV/11718_1119, 288 p.

Belcher, W.R., ed., 2004, Death Valley regional ground-water flow system, Nevada and California-Hydrogeologic framework and transient ground-water flow model: U.S. Geological Survey Scientific Investigations Report 2004-5205, 408 p.

Belcher, W.R., Elliott, P.E., and Geldon, A.L., 2001, Hydraulic-property estimates for use with a transient ground-water flow model of the Death Valley regional ground-water flow system, Nevada and California: U.S. Geological Survey Water-Resources Investigations Report 01-4120, 28 p.

Blankennagel, R.K., and Weir, J.E., Jr., 1973, Geohydrology of the eastern part of Pahute Mesa, Nevada Test Site, Nye County, Nevada: U.S. Geological Survey Professional Paper 712-B, 35 p. 
D’Agnese, F.A., Faunt, C.C., and Turner, A.K., 1998, An estimated potentiometric surface of the Death Valley region, Nevada and California, developed using Geographic Information System and automated interpolation techniques: U.S. Geological Survey Water-Resources Investigations Report 97-4052, p.

Doty, G.C., and Thordarson, William, 1983, Water table in rocks of Cenozoic and Paleozoic age, 1980, Yucca Flat, Nevada Test Site, Nevada: U.S. Geological Survey WaterResources Investigation Report 83-4067, 1 pl.

Ervin, E.M., Luckey, R.R., and Burkhardt, D.J., 1993, Revised potentiometric-surface map, Yucca Mountain and vicinity, Nevada: U.S. Geological Survey Water-Resources Investigation Report 93-4000, 17 p., 1 pl.

Fenelon, J.M., 2000, Quality assurance and analysis of water levels in wells on Pahute Mesa and vicinity, Nevada Test Site, Nye County, Nevada: U.S. Geological Survey WaterResources Investigations Report 00-4014, 29 p.

Fenelon, J.M., 2005, Analysis of ground-water levels and associated trends in Yucca Flat, Nevada Test Site, Nye County, Nevada, 1951-2003: U.S. Geological Survey Scientific Investigations Report 2005-5175, 87 p.

Fenelon, J.M., 2006, Database of ground-water levels in the vicinity of Rainier Mesa, Nevada Test Site, Nye County, Nevada, 1957-2005: U.S. Geological Survey Data Series 190, version 1.10, October 2007, 14 p.

Fenske, P.R., and Carnahan, C.L., 1975, Water table and related maps for Nevada Test Site and Central Nevada Test Area: U.S. Energy Research and Development Administration, Nevada Operations Office Report NVO-1253-9, $18 \mathrm{p}$.

Fryer, William, Domski, Paul, and Farnham, Irene, 2006, Analysis of FY 2005/2006 hydrologic testing and sampling results for well ER-12-4, Nevada Test Site, Nye County, Nevada: Stoller-Navarro Joint Venture Report S-N/99205-083, 98 p., 2 app.

Hale, G.S., Trudeau, D.T., and Savard, C.S., 1995, Waterlevel data from wells and test holes through 1991 and potentiometric contours as of 1991 for Yucca Flat, Nevada Test Site, Nye County, Nevada: U.S. Geological Survey Water-Resources Investigation Report 95-4177, 1 pl.

Hevesi, J.A., Flint, A.L., and Flint, L.E., 2003, Simulation of net infiltration and potential recharge using a distributedparameter watershed model of the Death Valley region, Nevada and California: U.S. Geological Survey WaterResources Investigations Report 03-4090, 161 p.
Hildenbrand, T.G., Phelps, G.A., and Mankinen, E.A., 2006, Inversion of gravity data to define the pre-Cenozoic surface and regional structures possibly influencing groundwater flow in the Rainier Mesa region, Nye County, Nevada: U.S. Geological Survey Open-File Report 2006-1299, 28 p.

Laczniak, R.J., Cole, J.C., Sawyer, D.A., and Trudeau, D.A., 1996, Summary of hydrogeologic controls on ground-water flow at the Nevada Test Site, Nye County, Nevada: U.S. Geological Survey Water-Resources Investigations Report 96-4109, 59 p.

Meinzer, O.E., 1923, Outline of ground-water hydrology, with definitions: U.S. Geological Survey Water-Supply Paper 494, $71 \mathrm{p}$.

National Security Technologies, LLC, 2007, A hydrostratigraphic model and alternatives for the groundwater flow and contaminant transport model of Corrective Action Unit 99-Rainier Mesa-Shoshone Mountain, Nye County, Nevada: U.S. Department of Energy Report DOE/NV/25946-146, 302 p.

O’Hagan, M.D., and Laczniak, R.L., 1996, Ground-water levels beneath eastern Pahute Mesa and vicinity, Nevada Test Site, Nye County, Nevada: U.S. Geological Survey Water-Resources Investigations Report 96-4042, 1 sheet.

Robinson, J.H., 1984, Ground-water level data and preliminary potentiometric surface maps, Yucca Mountain and vicinity, Nye County, Nevada: U.S. Geological Survey WaterResources Investigation Report 84-4197, 8 p.

Russell, C.E., Hess, J.W., and Tyler, S.W., 1987, Hydrogeologic investigations of flow in fractured tuffs, Rainier Mesa, Nevada Test Site, in Evans, D.D., and Nicholson, T.J., eds., Flow and transport through unsaturated fractured rock: American Geophysical Union Monograph 42, p. 43-50.

Sawyer, D.A., Fleck, R.J., Lanphere, M.A., Warren, R.G., Broxton, D.E., and Hudson, M.R., 1994, Episodic caldera volcanism in the Miocene southwestern Nevada volcanic field-Revised stratigraphic framework, ${ }^{40} \mathrm{Ar} /{ }^{39} \mathrm{Ar}$ geochronology, and implications for magmatism and extension: Geological Society of America Bulletin, v. 106, no. 10, p. $1304-1318$. 
Slate, J.L, Berry, M.E., Rowley, P.D., Fridrich, C.J., Morgan, K.S., Workman, J.B., Young, O.D., Dixon, G.L., Williams, V.S., McKee, E.H., Ponce, D.A., Hildenbrand, T.G., Swadley, W.C., Lundstrom, S.C., Ekren, E.B., Warren, R.G., Cole, J.C., Fleck, R.J., Lanphere, M.A., Sawyer, D.A., Minor, S.A., Grunwald, D.J., Laczniak, R.J., Menges, C.M., Yount, J.C., and Jayko, A.S., 2000, Digital geologic map of the Nevada Test Site and vicinity, Nye, Lincoln, and Clark Counties, Nevada, and Inyo County, California: U.S. Geological Survey Open-File Report 99-554A, 53 p, scale 1:120,000, accessed September 2007 at http://pubs.usgs. gov/of/1999/ofr-99-0554/

Soulé, D.A., 2006, Climatology of the Nevada Test Site: National Oceanic and Atmospheric Administration Air Resources Laboratory Technical Memorandum SORD 2006-3, 165 p.

Stoller-Navarro Joint Venture, 2006, Analysis of ER-12-3 FY 2005 hydrologic testing, Nevada Test Site, Nye County, Nevada: Stoller-Navarro Joint Venture Report S-N/99205-080, $89 \mathrm{p}$.

Thordarson, William, 1965, Perched ground water in zeolitized-bedded tuff, Rainier Mesa and vicinity, Nevada Test Site, Nevada: U.S. Geological Survey Open-File Report 66-13, 90 p.

Tucci, P., and Burkhardt, D.J., 1995, Potentiometric-surface map, 1993, Yucca Mountain and vicinity, Nevada: U.S. Geological Survey Water-Resources Investigations Report 95-4149, $15 \mathrm{p}$.
U.S. Department of Energy, 2000, United States nuclear tests, July 1945 through September 1992: U.S. Department of Energy Report DOE/NV—209 REV 15, 162 p.

U.S. Geological Survey, 2008, USGS/U.S. Department of Energy cooperative studies in Nevada: accessed January 16, 2008 at http://nevada.usgs.gov/doe nv/

Waddell, R.K., Robison, J.H., and Blankennagel, R.K., 1984, Hydrology of Yucca Mountain and vicinity, NevadaCalifornia-Investigative results through mid 1983: U.S. Geological Survey Water-Resources Investigations Report 84-4267, 72 p.

Winograd, I.J., and Thordarson, William, 1975, Hydrogeologic and hydrochemical framework, south-central Great Basin, Nevada-California, with special reference to the Nevada Test Site: U.S. Geological Survey Professional Paper 712-C, $126 \mathrm{p}$.

Workman, J.B., Menges, C.M., Page, W.R., Taylor, E.M., Ekren, E.B., Rowley, P.D., Dixon, G.L., Thompson, R.A., and Wright, L.A., 2002, Geologic map of the Death Valley ground-water model area, Nevada and California: U.S. Geological Survey Miscellaneous Field Studies Map MF-2381-A, scale 1:250,000, accessed September 2007 at http://pubs.usgs.gov/mf/2002/mf-2381/ 


\section{Appendix 1. Water Levels Measured in the Rainier Mesa and Shoshone Mountain Area, Nevada Test Site, Nye County, Nevada, 1957-2007.}

Hydrographs and locations for the 172 wells that have measured water levels in the Rainier Mesa and Shoshone Mountain area are tabulated and can be displayed interactively from a Microsoft ${ }^{\circledR}$ Excel workbook. The workbook is designed to be an easy-to-use tool to view water levels and other associated information for wells in the study area. Information for an individual well can be selected by using the AutoFilter option available in Excel. The information presented for a selected well includes:

- USGS site identification number,

- Well name,

- Land-surface altitude,

- Water-level date,

- Water-level depth,

- Water-level altitude,

- Water-level qualifier,

- Water-level source,

- Water-level method,

- Water-level accuracy,

- Water-level status,

- Water-level remark,

- Use flag,

- NTS area number,

- Latitude, and

- Longitude.

Appendix 1 data are available at http://pubs.usgs.gov/sir/2008/5044 


\section{Appendix 2. Mean Water Levels, Well Characteristics, and Water-Level Remarks for Wells Used to Develop Water-Level Contours in the Rainier Mesa and Shoshone Mountain Area, Nevada Test Site, Nye County, Nevada.}

A summary table that includes the 133 wells used to develop water-level contours in the Rainier Mesa and Shoshone Mountain area is available in a Microsoft ${ }^{\circledR}$ Excel workbook. For each well, the mean of the water levels considered representative of predevelopment conditions is presented. Remarks stating the relevance of each mean predevelopment water level as used for water-level contouring also are documented. The information presented for each well includes:

- Well name,

- USGS site identification number,

- NTS hole name,

- NTS area number,

- Latitude,

- Longitude,

- Land-surface altitude,

- Depth drilled,

- Well depth,

- Top and bottom opening altitude,

- Contributing subsurface hydrologic unit types,

- Number of water levels,

- Water-level date range,

- Mean water-level altitude,

- Water-column length,

- Map use of water level, and

- Water-level remark.

Appendix 2 data are available at http://pubs.usgs.gov/sir/2008/5044 


\section{Appendix 3. Hydrostratigraphic Units and Subsurface Hydrologic Unit Types for Wells in the Rainier Mesa and Shoshone Mountain Area, as Projected From Hydrostratigraphic Framework Models, Nevada Test Site, Nye County, Nevada.}

\footnotetext{
The hydrostratigraphic units (HSUs) and corresponding subsurface hydrologic unit types (SHUTs) for the 133 wells identified as having one or more water-level measurements representative of predevelopment ground-water conditions are tabulated and can be displayed interactively from a Microsoft ${ }^{\circledR}$ Excel workbook. The workbook is designed to view a stratigraphic column interpreted from a hydrostratigraphic framework model, the mean predevelopment water-level altitude, and basic well-construction information for wells in the study area. Information for an individual well can be viewed by selecting the well from a column-header dropdown list.
}

Appendix 3 data are available at http://pubs.usgs.gov/sir/2008/5044 
This page intentionally left blank. 
For more information contact:

Director, Nevada Water Science Center

U.S. Geological Survey

2730 N. Deer Run Road

Carson City, Nevada 89701

http://nevada.usgs.gov 


$$
\text { खू }
$$

